\title{
Metal to phosphorus stoichiometries for freshwater phytoplankton in three remote lakes
}

\author{
Aine M Gormley-Gallagher ${ }^{\text {Corresp., }}{ }^{1}$, Richard W Douglas ${ }^{2}$, Brian Rippey ${ }^{3}$ \\ ${ }^{1}$ School of Environmental Sciences, University of Ulster, Coleraine, United Kingdom \\ 2 School of Geography \& Environmental Sciences, University of Ulster, Coleraine, United Kingdom \\ 3 School of Geography and Environmental Sciences, Ulster University, Coleraine, United Kingdom \\ Corresponding Author: Aine M Gormley-Gallagher \\ Email address: a.m.gormley-gallagher@rug.nl
}

Simultaneous measurements of changes in phytoplankton biomass and the metal and phosphorus (P) content of cells have been captured to attest metal to P stoichiometries for freshwater phytoplankton. Three Scottish lakes that have received high, medium or low metal contamination from the atmosphere were selected for study. Phytoplankton cells were collected and Inductively Coupled Plasma-Mass Spectrometry was used to measure their lead $(\mathrm{Pb})$, cadmium (Cd), mercury $(\mathrm{Hg})$, copper $(\mathrm{Cu})$, zinc $(\mathrm{Zn})$, nickel (Ni), chromium $(\mathrm{Cr})$, manganese $(\mathrm{Mn})$, cobalt $(\mathrm{Co})$ and $\mathrm{P}$ content. Increased phytoplankton growth in the lakes resulted in significant algae growth dilution of the mass-specific $\mathrm{Pb}, \mathrm{Cd}, \mathrm{Hg}, \mathrm{Cu}, \mathrm{Ni}$ and $\mathrm{Cr}$ in the phytoplankton. Changes in the phytoplankton cell count and their $\mathrm{Hg}, \mathrm{Pb}, \mathrm{Cd}$, $\mathrm{Cu}, \mathrm{Mn}, \mathrm{Co}, \mathrm{Ni}$ and $\mathrm{Cr}$ concentrations showed the process of algae bloom dilution to be subject to exponential decay, which accelerated in the order of $\mathrm{Mn}<\mathrm{Cu}<\mathrm{Ni}<\mathrm{Pb}$ and $\mathrm{Cd}$ $<\mathrm{Cr}$ and $\mathrm{Hg}<\mathrm{Co}$. This indicated a metabolic and detoxification mechanism was involved in the active selection of metals. For the first time simultaneous measurements of metals and $\mathrm{P}$ stoichiometry in freshwater phytoplankton are reported. The mean metal to $\mathrm{P}$ stoichiometry generated was $\left(\mathrm{C}_{106} \mathrm{P}_{1} \mathrm{~N}_{16}\right)_{1000} \mathrm{~Pb}_{0.019} \mathrm{Hg}_{0.00004} \mathrm{Cu}_{0.013} \mathrm{Cd}_{0.005} \mathrm{Cr}_{0.2} \mathrm{Co}_{0.0008} \mathrm{Mn}_{0.2} \mathrm{Ni}_{0.012}$ based on field measurements and the Redfield average $\mathrm{C}, \mathrm{N}$ and $\mathrm{P}$ stoichiometry of $\left(\mathrm{CH}_{2} \mathrm{O}\right)_{106}\left(\mathrm{NH}_{3}\right)_{16} \mathrm{H}_{3} \mathrm{PO}_{4}$. 


\section{Metal to phosphorus stoichiometries for freshwater phytoplankton in}

\section{2 three remote lakes}

3 Aine M. Gormley-Gallagher ${ }^{2}$, Richard W. Douglas and Brian Rippey

4 School of Geography and Environmental Sciences, Ulster University, Coleraine, Northern Ireland, BT52 1SA.

$5 \quad{ }^{2}$ Corresponding author current address: University College Groningen, University of Groningen, 9712 CP

6 Groningen, Netherlands.

\section{Abstract}

9 Simultaneous measurements of changes in phytoplankton biomass and the metal and phosphorus

10 (P) content of cells have been captured to attest metal to P stoichiometries for freshwater

11 phytoplankton. Three Scottish lakes that have received high, medium or low metal contamination

12 from the atmosphere were selected for study. Phytoplankton cells were collected and Inductively

13 Coupled Plasma-Mass Spectrometry was used to measure their lead $(\mathrm{Pb})$, cadmium $(\mathrm{Cd})$,

14 mercury $(\mathrm{Hg})$, copper $(\mathrm{Cu})$, zinc $(\mathrm{Zn})$, nickel $(\mathrm{Ni})$, chromium $(\mathrm{Cr})$, manganese $(\mathrm{Mn})$, cobalt $(\mathrm{Co})$

15 and $\mathrm{P}$ content. Increased phytoplankton growth in the lakes resulted in significant algae growth

16 dilution of the mass-specific $\mathrm{Pb}, \mathrm{Cd}, \mathrm{Hg}, \mathrm{Cu}, \mathrm{Ni}$ and $\mathrm{Cr}$ in the phytoplankton. Changes in the

17 phytoplankton cell count and their $\mathrm{Hg}, \mathrm{Pb}, \mathrm{Cd}, \mathrm{Cu}, \mathrm{Mn}, \mathrm{Co}, \mathrm{Ni}$ and $\mathrm{Cr}$ concentrations showed the

18 process of algae bloom dilution to be subject to exponential decay, which accelerated in the order

19 of $\mathrm{Mn}<\mathrm{Cu}<\mathrm{Ni}<\mathrm{Pb}$ and $\mathrm{Cd}<\mathrm{Cr}$ and $\mathrm{Hg}<\mathrm{Co}$. This indicated a metabolic and detoxification

20 mechanism was involved in the active selection of metals. For the first time simultaneous

21 measurements of metals and P stoichiometry in freshwater phytoplankton are reported. The mean

22 metal to $\mathrm{P}$ stoichiometry generated was $\left(\mathrm{C}_{106} \mathrm{P}_{1} \mathrm{~N}_{16}\right){ }_{1000} \mathrm{~Pb}_{0.019} \mathrm{Hg}_{0.00004} \mathrm{Cu}_{0.013} \mathrm{Cd}_{0.005} \mathrm{Cr}_{0.2} \mathrm{Co}_{0.0008}$ 
$23 \mathrm{Mn}_{0.2} \mathrm{Ni}_{0.012}$ based on field measurements and the Redfield average $\mathrm{C}, \mathrm{N}$ and $\mathrm{P}$ stoichiometry of $24\left(\mathrm{CH}_{2} \mathrm{O}\right)_{106}\left(\mathrm{NH}_{3}\right)_{16} \mathrm{H}_{3} \mathrm{PO}_{4}$. 


\section{Introduction}

Phytoplankton cells are typically composed of carbon $(\mathrm{C})$, nitrogen $(\mathrm{N})$ and phosphorus (P) and have a commonly accepted average stoichiometry of $\left(\mathrm{CH}_{2} \mathrm{O}\right)_{106}\left(\mathrm{NH}_{3}\right)_{16} \mathrm{H}_{3} \mathrm{PO}_{4}($ Redfield et al., 1963; Sanudo-Wilhelmy et al., 2004). Phytoplankton can exploit iron (Fe), manganese $(\mathrm{Mn})$, zinc $(\mathrm{Zn})$, copper $(\mathrm{Cu})$ and nickel $(\mathrm{Ni})$ for $\mathrm{N}$ acquisition, oxygen cycling, chlorophyll synthesis, and sulfate reduction (Moffett et al., 1997; Twining et al., 2004). These nutrient metals can be replaced at their metabolic site by micronutrient metals such as cadmium $(\mathrm{Cd})$, mercury $(\mathrm{Hg})$, lead $(\mathrm{Pb})$ and chromium $(\mathrm{Cr})$ (Bruland et al., 1978; Sunda and Huntsman, 1998).

The cells can accumulate metals because they have a large surface area that has hydrophilic groups or hydroxy complexes with O-containing donor groups (-COH: -COOH; $\mathrm{P}(\mathrm{O})(\mathrm{OH})_{2}$ ), which bind to ambient metal cations (Vasconcelos et al., 2002). These sites on the cell surface are ligands from which metals can either dissociate back into solution or travel into the cytoplasm (Sunda and Huntsman, 1998). This has been reported as a dominant process of trace metal removal from solution (Whitfield, 2001; Lohan et al., 2005). Alternatively, cellular metal uptake may also occur through transport proteins or porins that are embedded in the outer membrane and allow for non-selective passive diffusion of metal ions across the outer membrane (Ma et al., 2009).

Due to the realisation of the proclivity of metals to bind non-specifically to cell surfaces, studies have extended the concept of Redfield et al.'s nutrient stoichiometry to include metals. Ho et al. (2003) calculated a mean stoichiometry (mol:mol) of $\left(\mathrm{C}_{124} \mathrm{~N}_{16} \mathrm{P}_{1} \mathrm{~S}_{1.3} \mathrm{~K}_{1.7} \mathrm{Mg}_{0.56} \mathrm{Ca}_{0.5}\right)_{1000} \mathrm{Sr}_{5.0} \mathrm{Fe}_{7.5} \mathrm{Zn}_{0.80} \mathrm{Cu}_{0.38} \mathrm{Co}_{0.19} \mathrm{Cd}_{0.21} \mathrm{Mo}_{0.03}{ }^{*}$, while Twining et al. (2004) found $\left(\mathrm{C}_{72} \mathrm{P}_{1} \mathrm{~S}_{0.70}\right)_{1000} \mathrm{Zn}_{5.4} \mathrm{Fe}_{1.8} \mathrm{Ni}_{0.61} \mathrm{Mn}_{0.26}$ for marine phytoplankton. Research has identified the risk posed to ecosystems and humans via toxic metal accumulation by

\footnotetext{
${ }^{*}$ Sulphur (S), potassium (K), magnesium (Mg), calcium (Ca), strontium (Sr), cobalt (Co), molybdenum (Mo).
} 
49 phytoplankton with consequential transfer through the aquatic food chain (UNECE, 1998; Chen

50 el al., 2000; Schultz and Seaward, 2000). As a result, the United Nations Economic Commission

51 for Europe adopted the Heavy Metals Protocol to encourage modelling, research and descriptions

52 of metal pathways (UNECE, 1998). Yet simultaneous measurements of metal to nutrient

53 stoichiometry in freshwater phytoplankton have only been estimated (Wang and Dei, 2006).

54 When Reynolds and Hamilton-Taylor (1992) calculated stoichiometries of $\mathrm{C}_{106} \mathrm{P}_{1} \mathrm{Zn}_{0.034}$

55 for Lake Windermere, United Kingdom (UK), they estimated P based on regressions of

56 dissolved $\mathrm{P}$ concentrations and the $\mathrm{C}$ : Si atomic ratio of 1:0.40 in phytoplankton cells. Likewise,

57 Sigg $(1985,1987)$ presented mean stoichiometries of $\mathrm{C}_{113} \mathrm{P}_{1} \mathrm{Zn}_{0.06} \mathrm{Cu}_{0.008}$ and

$58\left(\mathrm{CH}_{2} \mathrm{O}\right)_{106}\left(\mathrm{NH}_{3}\right)_{16} \mathrm{H}_{3} \mathrm{PO}_{4} \mathrm{Cu}_{0.0006} \mathrm{Zn}_{0.03}$ for the phytoplankton of Lake Constance and Lake Zurich

59 (Switzerland) respectively. However, the mean surface areas of the algae cells were estimated

60 from correlation of the organic material content of the settling particles using typical cell

61 dimensions of diatoms. Sigg therefore acknowledged that the stoichiometries are approximations

62 that could vary if different algal species were taken into account.

63 Another mechanism (in addition to the influence of surface communities) that has been

64 proposed to explain variations in metal to nutrient stoichiometries in phytoplankton is algae

65 bloom density dilution. If phytoplankton share a finite pool of metals and have a constant uptake,

66 enhanced lake productivity reduces metal concentrations per unit mass of phytoplankton (Chen

67 and Folt, 2005). Additionally, if the trace element to macronutrient (i.e. phosphorus or carbon)

68 ratios is a balance of net steady-state uptake and growth rates (Sunda and Huntsman, 1997, 2004)

69 - growth rates will increase as nutrients become more available, inducing a decline in cellular

70 element to nutrient ratios. This suggests that, because $\mathrm{P}$ is a limiting nutrient for phytoplankton

71 growth, increased cellular P would correlate with a decline in cellular metal concentrations. 
73 Biotic Ligand Models (BLM) (De Schamphelaere et al., 2005). When BLM were first

74 developed, they provided a way to predict the ambient metal concentration that will have an

75 effect (e.g. lethality) on organisms (e.g. fish), and emphasised the importance of including

76 biological ligand concentration (e.g. physiologically active sites at the gills of fish) for that

77 prediction (Di Toro et al., 2002). The models assumed a fixed rate of metal uptake occurred

78 according to ambient concentrations, thus they were extended to include ambient water

79 chemistry (Paquin et al., 2002). De Schamphelaere et al. (2005) then showed that cellular metal

80 concentrations were better than ambient metal concentrations for predicting the threat of toxicity

81 to freshwater phytoplankton. They stressed that cell surfaces should be used as the ligand for

82 metals in the same way as fish gills apply to the BLM for predicting metal toxicity to fish

83 species. Wang and Dei (2006) then showed that the metal to nutrient stoichiometry in

84 phytoplankton cells better predicts metal toxicity than cellular metal burden. Determining what

85 biogeochemical characteristics influence toxic metal uptake and accumulation in the aquatic food

86 chain is important for identifying communities and species at risk of adverse impacts from metal

87 contamination - and for developing management strategies to mitigate this risk (Ward et al., 88 2010).

89 The need for a simultaneous measurement of metal to nutrient (in this case P)

90 stoichiometry in freshwater phytoplankton will be addressed in this contribution. Our underlying

91 hypothesis is that cellular metal to $\mathrm{P}$ ratios decline as $\mathrm{P}$ becomes more available - and thus the

92 dilution of metals in freshwater phytoplankton is a function of increased phytoplankton growth.

\section{Site descriptions}


96 metal contamination from the atmosphere (Rippey and Douglas, 2004). One lake was selected in

97 each of the high, medium and low metal contaminated regions (Figure 1). The three lakes receive

98 metal contamination solely from atmospheric deposition - and thus metal contamination from

99 runoff or direct discharges would not influence our results (Murray, 1987; Rippey and Douglas,

100 2004). Additionally, the size and bathymetry of the lakes meant that regular sediment

101 resuspension events (and by association high suspended particulate matter) would be unlikely to

102 influence our investigation outcome (Hilton, 1985; Douglas and Rippey, 2000; Douglas et al.,

103 2003; Gormley-Gallagher et al., 2015).

104 In the following site descriptions, lake surface area, perimeter, altitude, grid reference,

105 catchment area, maximum basin relief, and distance from the sea and to the nearest village were

106 calculated and/or obtained using the OS Landranger ${ }^{\circledR}$ Memory-Map ${ }^{\mathrm{TM}}$ V5 edition (2006) for

107 northern and southern Scotland (Licence number PU 100034184). The maximum lake depths

108 were based on collected field data, while catchment geology, vegetation and soil type were

109 derived from Patrick et al. (1991, 1995).

110 Loch Coire nan Arr has a surface area of 13.21 ha, a maximum lake depth of $11 \mathrm{~m}$ and a

111 catchment area of $8.45 \mathrm{~km}^{2}$ (Table 1). It is the most northerly of the three sites and lies in the

112 region of low metal contamination from the atmosphere (Figure 1). Permission for sampling the

113 site was obtained from The Applecross Trust, a conservation charity responsible for the

114 management of the lake (contact: admin@applecross.org.uk).

115 Loch Doilet has a surface are of 51.55 ha, a maximum lake depth of $16 \mathrm{~m}$ and a

116 catchment area of $33.51 \mathrm{~km}^{2}$ (Table 1). The lake, lying northwest of the Ben Nevis Mountain

117 range, is the largest of the three lakes and has received moderate metal contamination from the 
118 atmosphere (Figure 1). The catchment rises from the lake to a peak of approximately $720 \mathrm{~m}$.

119 Permission for sampling the site was obtained from the Forestry Commission Scotland, a UK

120 non-ministerial government department responsible for the management of the lake (contact:

121 lochaber@forestry.gsi.gov.uk).

122 Loch Urr has a surface area of 47 ha with a maximum lake depth of $13 \mathrm{~m}$ (Table 1). It

123 lies in the Dumfries and Galloway region of south-west Scotland, an area that has received high

124 metal contamination from the atmosphere (Figure 1). The lake drains the smallest of the three

125 catchments with an area of $7.73 \mathrm{~km}^{2}$. Permission for sampling the site was obtained from the Urr

126 District Salmon Fisheries Board (contact: mail@gallowayfisheriestrust.org). 


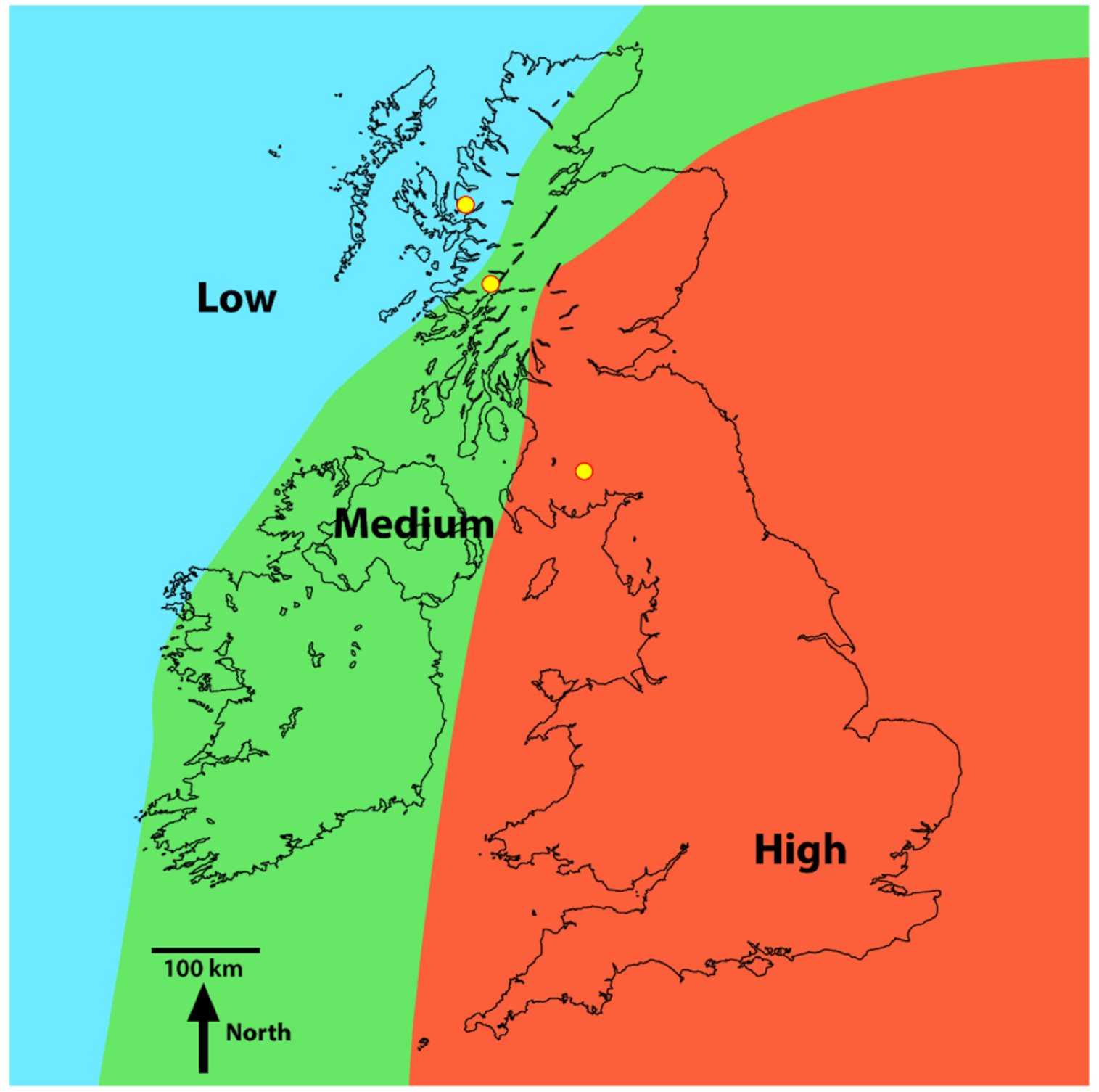

128 Figure 1. Regions of high, medium and low $\mathrm{Pb}$ contamination of lake sediment due to

129 atmospheric deposition (from Rippey and Douglas, 2004). The yellow circles in in the low,

130 medium and high regions of contamination indicate the locations of Loch Coire nan Arr, Loch

131 Doilet and Loch Urr, respectively (Gormley-Gallagher et al., 2015).

133 Table 1. Summary of the site characteristics of Loch Coire nan Arr in northwestern Scotland,

134 Loch Doilet in western Scotland and Loch Urr in southern Scotland (Gormley-Gallagher, 2015). 


\begin{tabular}{|c|c|c|c|}
\hline & Loch Coire nan Arr & Loch Doilet & Loch Urr \\
\hline Grid Reference & NG 808422 & NM807677 & NX759864 \\
\hline Surface area & $13.21 \mathrm{ha}$ & 51.55 ha & 47.0 ha \\
\hline Perimeter & $1.86 \mathrm{~km}$ & $5.49 \mathrm{~km}$ & $4.2 \mathrm{~km}$ \\
\hline Maximum lake depth & $11 \mathrm{~m}$ & $16 \mathrm{~m}$ & $13.2 \mathrm{~m}$ \\
\hline Lake volume & $5.6 \times 10^{5} \mathrm{~m}^{3}$ & $4.1 \times 10^{6} \mathrm{~m}^{3}$ & $2.35 \times 10^{6} \mathrm{~m}^{3}$ \\
\hline $\begin{array}{l}\text { Distance upstream from } \\
\text { sea }\end{array}$ & $2.03 \mathrm{~km}$ & $6.2 \mathrm{~km}$ & $22.7 \mathrm{~km}$ \\
\hline $\begin{array}{l}\text { Aerial distance from } \\
\text { nearest village }\end{array}$ & $8.91 \mathrm{~km}$ (Lochcarron) & $8.84 \mathrm{~km}$ (Strontian) & 6.6 km (Monaive) \\
\hline Elevation/altitude & $125 \mathrm{~m}$ & $8 \mathrm{~m}$ & 193 m \\
\hline Catchment area & $8.45 \mathrm{~km}^{2}$ & $33.51 \mathrm{~km}^{2}$ & $7.73 \mathrm{~km}^{2}$ \\
\hline Catchment geology & Torridonian Sandstone & Schists and gneiss & Granite / gneiss \\
\hline Catchment vegetation & Confiers < $1 \%$ & $\begin{array}{l}\text { Conifers }-50 \% \text {, } \\
\text { moorland }-50 \%\end{array}$ & Moorland - $100 \%$ \\
\hline Catchment soils & Peat & Peats & $\begin{array}{l}\text { Podsol, peaty gley } \\
\text { blanket peat }\end{array}$ \\
\hline
\end{tabular}

\section{Sampling}

Sampling campaigns were conducted on ten occasions: early June, late June, July, August and September 2006, and again in March, May, June, July and September 2007 at each of the three lakes. Before fieldwork, all sample containers were prepared to reduce metal contamination and prevent adsorption losses to the container walls (Yu et al., 2003). sample was for the analysis of chlorophyll- $a$, total phosphorus (TP) and $\mathrm{pH}$. The second was for analysis of total metal concentrations. The third was for phytoplankton identification and calculations of biomass. The water was taken from a central location $(6 \mathrm{~m})$ near the deepest point of the lake using a Perspex Ruttner sampler, as recommended by Sykes et al. (1999).

149 phytoplankton. An adjustment was made to the standard nets to separate the zooplankton during

150 each haul using the approach set out by Ho et al. (2007). Two filters, one of $20 \mu \mathrm{m}$ and one of 
$151250 \mu \mathrm{m}$ were stacked on top of each other with a $35 \mathrm{~mm}$ spacer such that water flowed first

152 through the $250 \mu \mathrm{m}$ and then the $20 \mu \mathrm{m}$ filter. The upper filter of mesh $250 \mu \mathrm{m}$ was a sufficient

153 size to trap the zooplankton but allow the smaller phytoplankton to be trapped in the smaller 20

$154 \mu \mathrm{m}$ mesh. This method potentially introduces sources of error. Firstly, by excluding

155 bacterioplankton (free floating bacterial component of the plankton) and phytoplankton $<20 \mu \mathrm{m}$

156 from the metals estimate, the relationships of phytoplankton metal concentrations and TP could

157 be affected. Secondly, possible clogging in the larger size fraction could lead to the selection of

158 smaller phytoplankton in the sample. However, when the two size fractions were microscopically

159 analysed, the zooplankton were not incorporated into the phytoplankton samples and

160 phytoplankton smaller than $250 \mu \mathrm{m}$ were not observed in the larger fraction. This may be

161 attributed to the fact that zooplankton production and the concentration of suspended particulate

162 matter are generally low in the lakes (Monteith et al., 2007; Murphy et al., 2014; Gormley-

163 Gallagher et al., 2015). The success of this method has also been demonstrated by Donald (2004)

164 and in the larger study from which this investigation stems (Gormley, 2008). Furthermore, given

165 the sampling difficulty in collecting sufficient uncontaminated biomass for metal analysis,

166 abating sample handling by separating the plankton assemblages in this manner in-situ was

167 deemed critical to minimise the possibility of metal contamination (Ho et al., 2007).

168 The water samples collected for phytoplankton identification and biomass calculations

169 were transferred on site from LDPE bottles to acid washed scintillation vials $(25 \mathrm{ml})$ that were

170 pre-prepared with glutaraldehyde (Electron Microscopy grade, EMS, Pennsylvania, U.S.A) to

171 produce a final concentration of $2 \%(\mathrm{v} / \mathrm{v})$.

172 The net haul material was transferred to a total of 36 polyethylene acid cleaned sampling

173 vials $(32 \mathrm{ml})$ at each site (AGB Scientific Ltd., UK). The vials used to store the net haul material 
174 were also pre-prepared to achieve $2 \%$ glutaraldehyde in the sample, except in this case, the

175 glutaraldehyde was passed through a Dowex 50-W X8-200 cation exchange resin (50X4-400; H-

176 form) to remove trace metals (Twinning et al., 2004).

177

178 Sample Analysis

179 TP concentrations were measured spectrometrically after digestions at $882 \mathrm{~nm}$ (Murphy

180 and Riley, 1962; Eisenreich et al., 1975). Chlorophyll- $a$ was extracted from the filtered samples

181 into $90 \% \mathrm{~V} / \mathrm{V}$ methanol, and the detection was performed with a spectrophotometer set at an

182 emission wavelength of $665 \mathrm{~nm}$ (Riemann, 1978). A Shimadzu UV-Mini 1240

183 Spectrophotometer was used for this at the Ulster University.

184 A Nikon-5400 inverted light microscope at $40 \mathrm{x}$ was used to examine the phytoplankton

185 samples and identify the species present. For this, $10 \mathrm{ml}$ of the lake water sample preserved in

186 glutaraldehyde was allowed to sediment in a settling chamber for no less than 8 hours. Blue-

187 green and green algae organisms were identified following the interactive keys produced by

188 Whitton et al. (2002, 2003). For those organisms that proved difficult to distinguish, a more

189 detailed text was consulted, i.e. John et al. (2002). The guidelines presented by Kelly (2000)

190 were followed to identify any cells representative of the Phylum Bacillariophyta and the Phylum

191 Fragilariophyceae (Diatoms).

192 During identification, the species/genre/groups were also counted and measured for

193 volume and surface area calculations following the procedures described by Olrik et al. (1998).

194 At least 10 length and width measurements were recorded for each species (wall to wall), and

195 when fewer than 10 cells were present, those present were measured. Cell counts were converted

196 to counts per volume of lake water. Cell volumes and surface areas were calculated using the 
197 geometric equations of Hillebrand et al. (1999). The volume of colonial and filamentous cells

198 was calculated from the volume of a single cell multiplied by the number of cells in each

199 colony/filament. The surface area of cells per volume of lake water was then calculated

200 following the guidelines of Olrik et al. (1998).

201

Acid digestions were prepared using methods found in Reynolds and Hamilton-Taylor

202 (1992). To achieve blank concentrations, 2 × $32 \mathrm{ml}$ vials of $2 \%$ glutaraldehyde were prepared

203 prior to each fieldwork session and brought on fieldwork to ensure they had the same sample

204 exposure. On return to the laboratory, a stream of Milli-Q water was used to fill the vial as it was

205 passed through the same plankton net filter used to collect the samples.

The phytoplankton samples were made soluble (digested) by treatment with hydrofluoric,

207 nitric and perchloric acid, following the acid digestion technique provided in Bock (1979). An

208 empty beaker (a reagent blank), and two samples of certified reference material (CRM) were

209 included with every batch (between 20-30 samples). The CRM used for this study was Chinese

210 stream sediment (GBW 07301) issued under the laboratory of the Government Chemist (LGC)

211 trademark (LGC Promochem, UK). The digested samples were stored in acid cleaned $25 \mathrm{ml}$

212 scintillation vials until further analysis with Inductively Coupled Plasma-Mass Spectrometry

213 (ICP-MS).

214 The XSeries ${ }^{\mathrm{I}}$ ICP-MS (ThermoFisher Scientific Cooperation) was used for the analysis of

215 metals and $\mathrm{P}$ in the samples (Table S1). All prepared standard solutions, samples and blanks

216 were acidified with $2 \%(\mathrm{w} / \mathrm{v}) \mathrm{HNO}_{3}{ }^{-}$(BDH Aristar, AGB Scientific Ltd., UK). The precision of

217 every element was assessed from replicate and, when possible, triplicate analysis of reference

218 material and of samples collected in fieldwork. This was found to be 5\% relative standard

219 deviation (RSD) or better, which is generally considered acceptable precision (Long et al., 1990). 
220 Also, instrument stability was indicated in the RSD of triplicate ICP-MS measurements for all 221 analytes of less than $5 \%$ in all cases, and in many cases less than $2 \%$.

222

223 Results

224 The measured concentrations of chlorophyll- $a$ and TP and modelled chlorophyll- $a$ 225 concentrations based on OEDC (1982) and Prairie et al. (1989) models for predicting 226 chlorophyll- $a$ based on TP concentrations are presented in Figure 2. The peak of TP 227 concentrations was recorded in mid-May 2007 for Loch Doilet $(23.5 \mu \mathrm{g} / 1)$ and Coire nan Arr $228(79.3 \mu \mathrm{g} / 1)$, whereas the peak in Loch Urr $(85.3 \mu \mathrm{g} / 1)$ occurred in late September 2006. The 229 chlorophyll- $a$ trends in Figure 2 show a peak during August/September 2006 for Loch Doilet $230(3.10 \mu \mathrm{g} / \mathrm{l})$ and September 2007 for Loch Urr $(23.0 \mu \mathrm{g} / \mathrm{l})$, whereas the peak in Loch Coire nan 231 Arr was during the month of July $2007(10.25 \mu \mathrm{g} / 1)$. The lowest chlorophyll-a concentrations 232 were 1.4, 1.5 and $2.7 \mu \mathrm{g} / 1$ respectively for Loch Coire nan Arr, Loch Doilet and Loch Urr. In 233 many cases, Figure 2 shows that an increase in TP is followed by a rise in chlorophyll-a on the 234 subsequent sampling occasion, particularly in Loch Coire nan Arr and Loch Urr. Also, the 235 patterns of chlorophyll- $a$ generally show similar timing in their fluctuations to that of the 236 predictions of chlorophyll- $a$ concentrations, notably in Loch Doilet. 

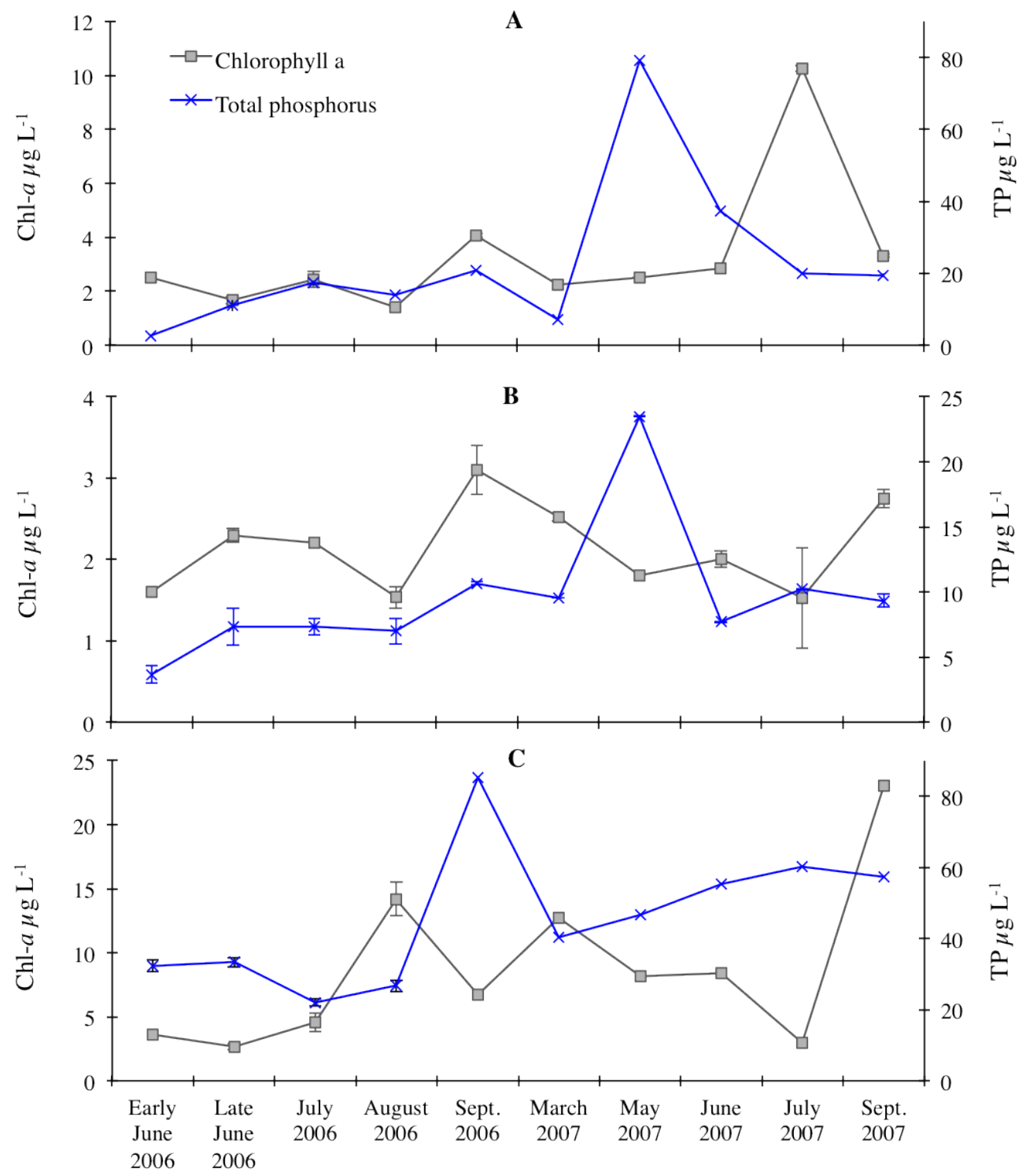

Sampling campaign

238 Figure 2. Chlorophyll- $a(\mathrm{Chl}-a)$ and total phosphorus (TP) concentrations measured in Loch

239 Coire nan Arr (A), Loch Doilet (B), and Loch Urr (C). The series keys located in the top left of

240 the diagram applies to each of the trend lines. Error bars are the standard error between the

241 triplicate measurements of each result $(n=3)$.

Figure 3 shows the concentrations of $\mathrm{Pb}, \mathrm{Hg}, \mathrm{Cd}, \mathrm{Cu}, \mathrm{Cr}, \mathrm{Co}, \mathrm{Mn}$ and $\mathrm{P}$ determined per

244 unit mass of the phytoplankton cells in Loch Coire nan Arr (A), Loch Doilet (B) and Loch Urr 
245 (C). The trend lines show high fluctuation across the sampling dates from early June 2006 to 246 September 2007. In the majority of cases the phytoplankton of Loch Urr held the lowest 247 concentrations of metals, but the highest concentration of $\mathrm{P}$ in the cells.
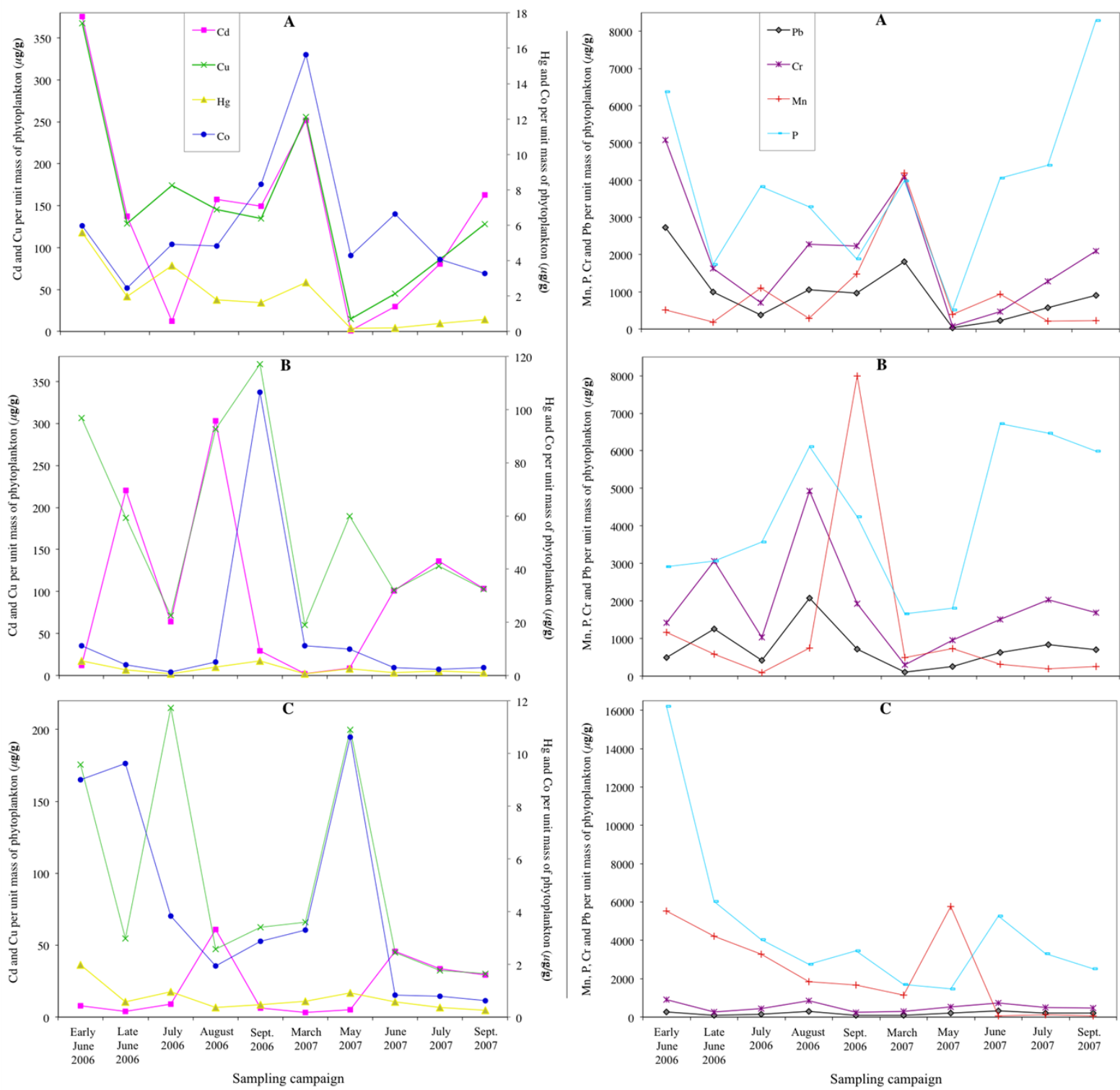

Figure 3. Concentrations of $\mathrm{Pb}, \mathrm{Hg}, \mathrm{Cd}, \mathrm{Cu}, \mathrm{Cr}, \mathrm{Co}, \mathrm{Mn}$ and $\mathrm{P}$ determined per unit mass of the phytoplankton cells collected in Loch Coire nan Arr (A), Loch Doilet (B), and Loch Urr (C). All

251 values are in $\mu \mathrm{g}$ of metal per $\mathrm{g}$ of phytoplankton. The series keys located in the A diagrams 252 applies to A, B and C. 
255 plotted against the TP concentrations of the three lakes on all sampling occasions in Figure 4

$256(\mathrm{n}=29)$. The scatterplots show a linear relationship with negative slope between each of the two

257 sets of variables. This indicates that the lower the lake TP concentration, the higher the

258 concentration of metals per unit mass of phytoplankton. Before completing the regression

259 analysis in Figure 4, the Kolmogorov-Smirnov and Shapiro-Wilk's tests on the normality of the

260 (raw) data showed the TP concentrations and the mass-specific metal concentration in the

261 phytoplankton to not be normally distributed $(p<0.05)$. However, using the log-transformed

262 metal concentrations and the cubic root of TP concentrations, the data showed normal

263 distribution $(p>0.05)$ in the Kolmogorov-Smirnov and Shapiro-Wilk's tests. 


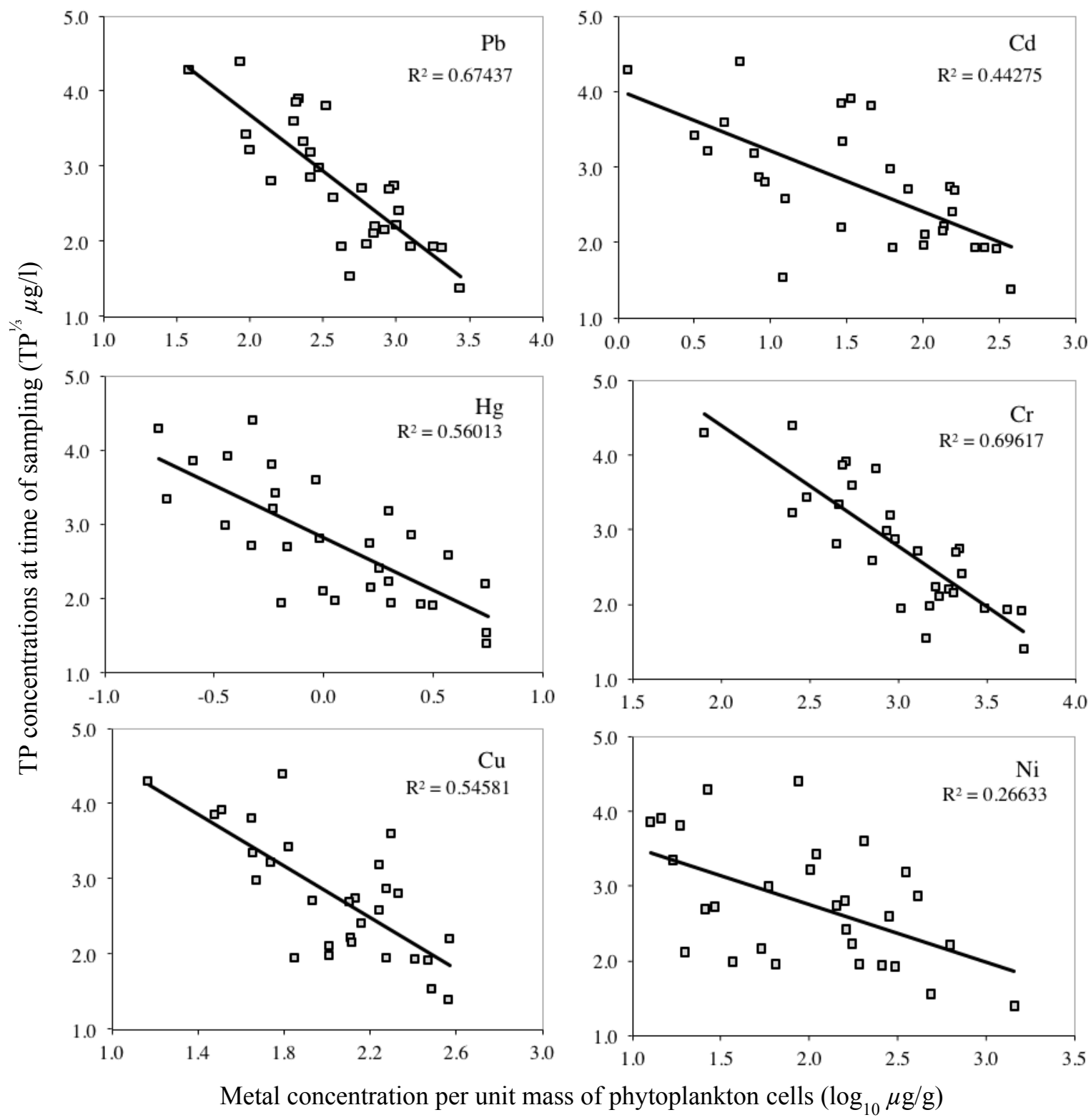

Figure 4. Correlation between $\mathrm{Pb}, \mathrm{Cd}, \mathrm{Hg}, \mathrm{Cr}, \mathrm{Cu}$ and $\mathrm{Ni}$ concentrations per unit mass of

267 phytoplankton and TP concentrations. The data was collected from the samples of all three lakes

268 during each sampling occasion $(n=29)$.

A bivariate correlation and regression analysis was carried out on the data in Figure 4

271 using the Statistical Package for Social Science (SPSS). The correlation coefficient and $p$-values 
272 of the tests confirms the patterns in the scatterplot that a significant negative relationship exists

273 between TP and $\mathrm{Pb}(\mathrm{r}=-0.823, p=0.00), \mathrm{Hg}(\mathrm{r}=-0.741, p=0.01), \mathrm{Cu}(\mathrm{r}=-0.748, p=0.00), \mathrm{Cd}$

$274(\mathrm{r}=-0.662, p=0.00), \mathrm{Cr}(\mathrm{r}=-0.837, p=0.00)$ and $\mathrm{Ni}(\mathrm{r}=-0.532, p=0.02)$ per unit mass of

275 phytoplankton in the lakes.

276 In contrast to $\mathrm{Pb}, \mathrm{Cd}, \mathrm{Hg}, \mathrm{Cu}, \mathrm{Cr}$ and $\mathrm{Ni}, \mathrm{Co}, \mathrm{Mn}$ and $\mathrm{P}$ per unit mass of phytoplankton

277 cells showed no clear relationship against the TP concentrations of the three lakes on all

278 sampling occasions. Examination of the bivariate correlation between the variables indicated no

279 significant relationship exists. Due to the extensive number of outliers and the lack of significant

280 correlation between the two sets of variables, a regression analysis was not suitable for the data.

Table 2 summarises the results of the multiple regressions carried out using a

282 combination of chlorophyll- $a$ and TP (as the independent variables) against metal $(\mathrm{Pb}, \mathrm{Cd}, \mathrm{Cr}$,

$283 \mathrm{Hg}, \mathrm{Cu}, \mathrm{Mn}, \mathrm{Co}$ ) to $\mathrm{P}$ ratios per unit mass of phytoplankton cells (the dependant variable). An

284 examination of the $t$-values in Table 2 indicates that TP is a significant predictor of the variations

285 in $\mathrm{Pb}: \mathrm{P}, \mathrm{Cd}: \mathrm{P}$ and $\mathrm{Cr}: \mathrm{P}$ ratios in cells at the 5\% level, but chlorophyll $a$ alone is not. For the $\mathrm{Hg}: \mathrm{P}$

286 ratio in cells, TP is a significant predictor at the $10 \%$ level, but chlorophyll- $a$ alone is not a

287 significant predictor.

288

289 Table 2. Summary of the simultaneous multiple regression performed using chlorophyll- $a$ and 290 total phosphorus (TP) as independent variables and the metal $(\mathrm{Pb}, \mathrm{Cd}, \mathrm{Cr}, \mathrm{Hg}, \mathrm{Cu}, \mathrm{Mn}, \mathrm{Co})$ to $\mathrm{P}$

291 ratios in phytoplankton cells from the three lakes as the dependant variable. Where $p<0.05$, the

292 relationship was significant at the $5 \%$ level, and where $p<0.10$, the relationship is significant at

293 the $10 \%$ level.

\begin{tabular}{|l|l|l|}
\hline & \multicolumn{2}{|c|}{ Metal : P ratio with } \\
Metal & Chlorophyll $a$ & Total phosphorus \\
\hline
\end{tabular}




\begin{tabular}{|c|c|c|c|c|} 
& $\mathbf{t}$ & Sig. & $\mathbf{t}$ & Sig. \\
\hline $\mathrm{Pb}$ & -0.474 & 0.640 & -2.541 & 0.017 \\
$\mathrm{Cd}$ & -0.179 & 0.859 & -2.457 & 0.021 \\
$\mathrm{Cr}$ & -0.384 & 0.704 & -2.781 & 0.010 \\
$\mathrm{Hg}$ & -1.018 & 0.318 & -1.710 & 0.099 \\
$\mathrm{Cu}$ & -0.507 & 0.616 & -1.189 & 0.245 \\
$\mathrm{Mn}$ & 0.167 & 0.896 & 0.683 & 0.501 \\
$\mathrm{Co}$ & -0.635 & 0.531 & 0.187 & 0.853 \\
\hline
\end{tabular}

296 correlation to exist between the Cr:P ratio in cells and TP $\left(r^{2}=0.3362\right)$.
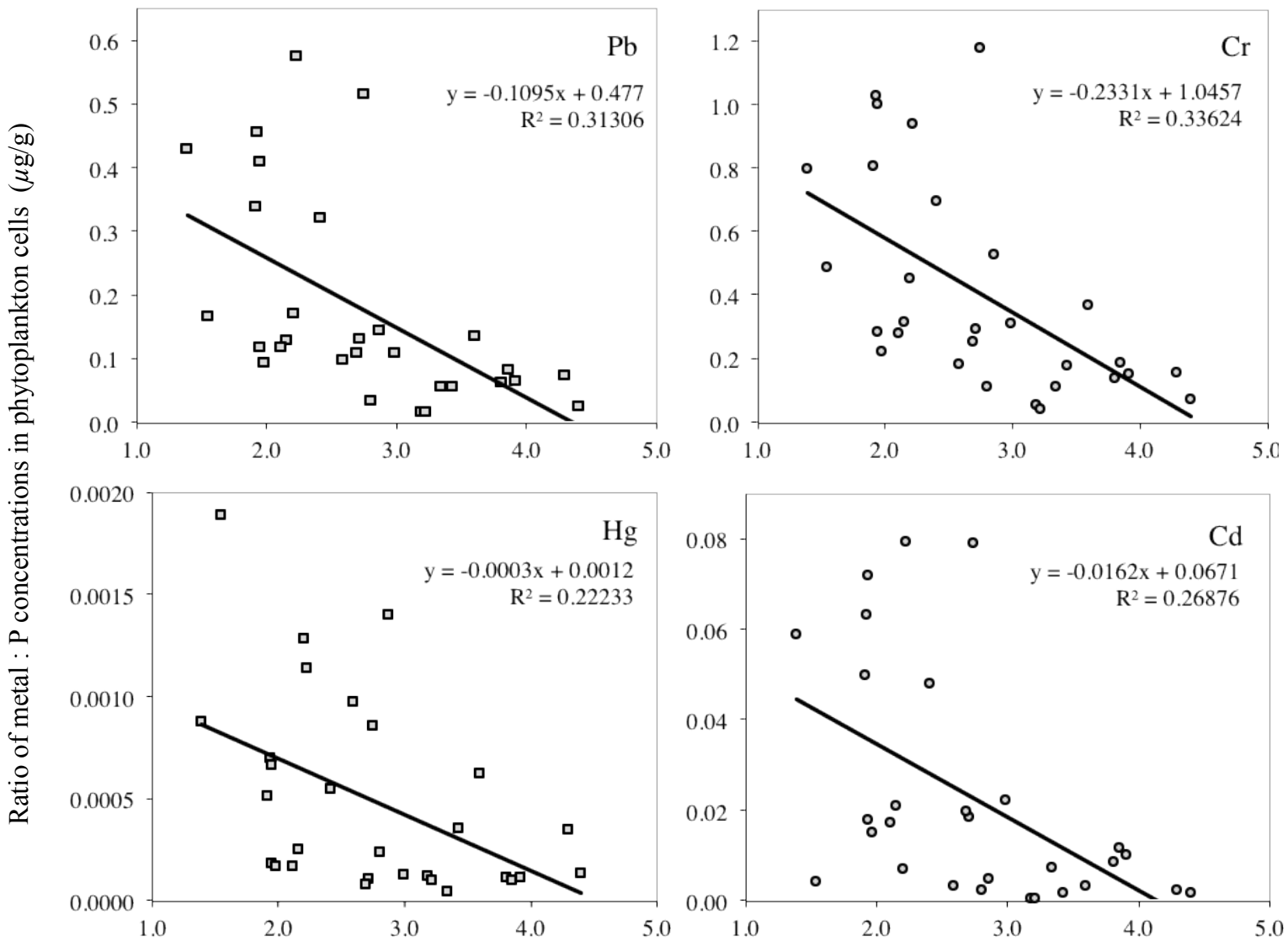

297

$\mathrm{TP}$ concentrations at time of sampling $\left(\mathrm{TP}^{1 / 3} \mu \mathrm{g} / \mathrm{l}\right)$

298 Figure 5. The relationship between $\mathrm{TP}$ and metal $(\mathrm{Pb}, \mathrm{Hg}, \mathrm{Cd}, \mathrm{Cr})$ to $\mathrm{P}$ ratios per unit mass of

299 phytoplankton cells in the three lakes. As a single variable in the multiple regression between the

300 metal:P ratios against chlorophyll- $a$ and TP, TP is a significant predictor of $\mathrm{Pb}, \mathrm{Cd}$ and $\mathrm{Cr}: \mathrm{P}$

301 ratios at the $5 \%$ level, and of $\mathrm{Hg}$ : $\mathrm{P}$ at the $10 \%$ level (Table 2). 
303 Figure 6 shows the dominant groups of phytoplankton (as a percentage of the total

304 volume), illustrating the shifts in species association of the phytoplankton over the sampling

305 period. Among these, the dominant groups in Loch Coire nan Arr (Figure 6A) were the

306 Chlorophytes (particularly Cosmarium sp.) and the Dinoflagellates (particularly Peridinium

307 willei). In Loch Doilet (Figure 6B), the Chlorophytes were also a dominant group, particularly

308 the filament Oedogonium sp. In contrast, Loch Urr (Figure 6C) had a greater abundance of the

309 blue-green algae, such as the genus Oscillatoria sp., which is from the prokaryotic group the

310 Cyanophytes. There was also a higher dominance of the Diatoms in Loch Urr in comparison to

311 the other lakes.

312 


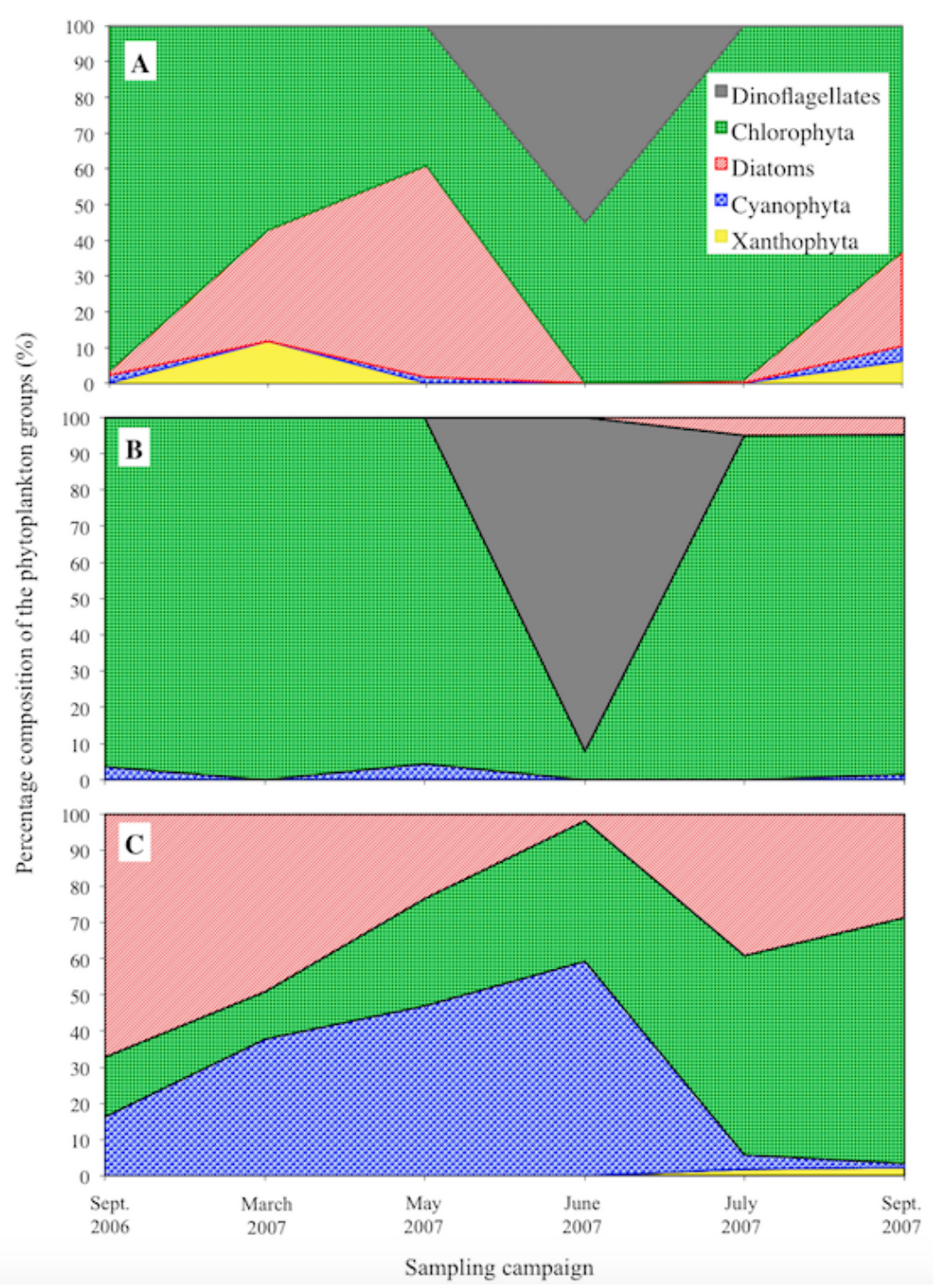

314

315 Figure 6. The dominant groups of phytoplankton (as a percentage of the total volume) in the

316 three lakes. The percentage composition is presented for Loch Coire nan Arr (A), Loch Doilet

317 (B) and Loch Urr (C). The series key located in diagram A applies to A, B and C.

The biomass, surface area and cell count calculated for Loch Coire nan Arr, Loch Doilet, 320 and Loch Urr are detailed in Table 3. Based on these data, the correlation between cells count 
321 and TP at the time of sampling was significant at the $5 \%$ level (Figure 7), however the

322 correlations between TP and cell surface area as well as biomass were not significant at the $5 \%$

323 level.

324

325 Table 3. Biomass, surface area and cell count determined for the three lakes on each of the

326 sampling occasions.

327

328

329

330

331

332

333

334

335

336

\begin{tabular}{|l|c|r|r|r|}
\hline \multicolumn{1}{|c|}{ Lake } & Date & \multicolumn{1}{c|}{$\begin{array}{c}\text { Biomass } \\
(\boldsymbol{\mu g} / \mathbf{l})\end{array}$} & $\begin{array}{c}\text { Surface area } \\
\left(\mathbf{m m}^{2} / \mathbf{l}\right)\end{array}$ & $\begin{array}{c}\text { Cell count } \\
(\mathbf{n o} / \mathbf{m l})\end{array}$ \\
\hline Loch Coire & 22.09 .06 & 4.4 & 3.1 & 4.7 \\
nan Arr & 23.03 .07 & 7.1 & 7.1 & 8.9 \\
& 22.05 .07 & 12.9 & 9.6 & 33.9 \\
& 21.06 .07 & 77.5 & 23.1 & 52.5 \\
& 25.07 .07 & 1.4 & 1.7 & 8.9 \\
& 01.09 .07 & 10.1 & 14.8 & 39.8 \\
\hline Loch Doilet & 22.09 .06 & 2.9 & 3.7 & 4.4 \\
& 23.03 .07 & 0.5 & 1.4 & 12.4 \\
& 22.05 .07 & 3.8 & 2.3 & 8.0 \\
& 21.06 .07 & 17.5 & 3.8 & 1.2 \\
& 24.07 .07 & 1.8 & 1.4 & 5.5 \\
& 31.08 .07 & 35.7 & 34.6 & 31.7 \\
\hline Loch Urr & 21.09 .06 & 63.6 & 3564.3 & 197.6 \\
& 23.03 .07 & 169.8 & 9278.3 & 172.3 \\
& 23.05 .07 & 178.2 & 138.9 & 183.3 \\
& 22.06 .07 & 69.3 & 48.6 & 99.2 \\
& 26.07 .07 & 115.0 & 1804.8 & 307.5 \\
& 02.09 .07 & 445.6 & 263.9 & 278.0 \\
\hline
\end{tabular}

337 


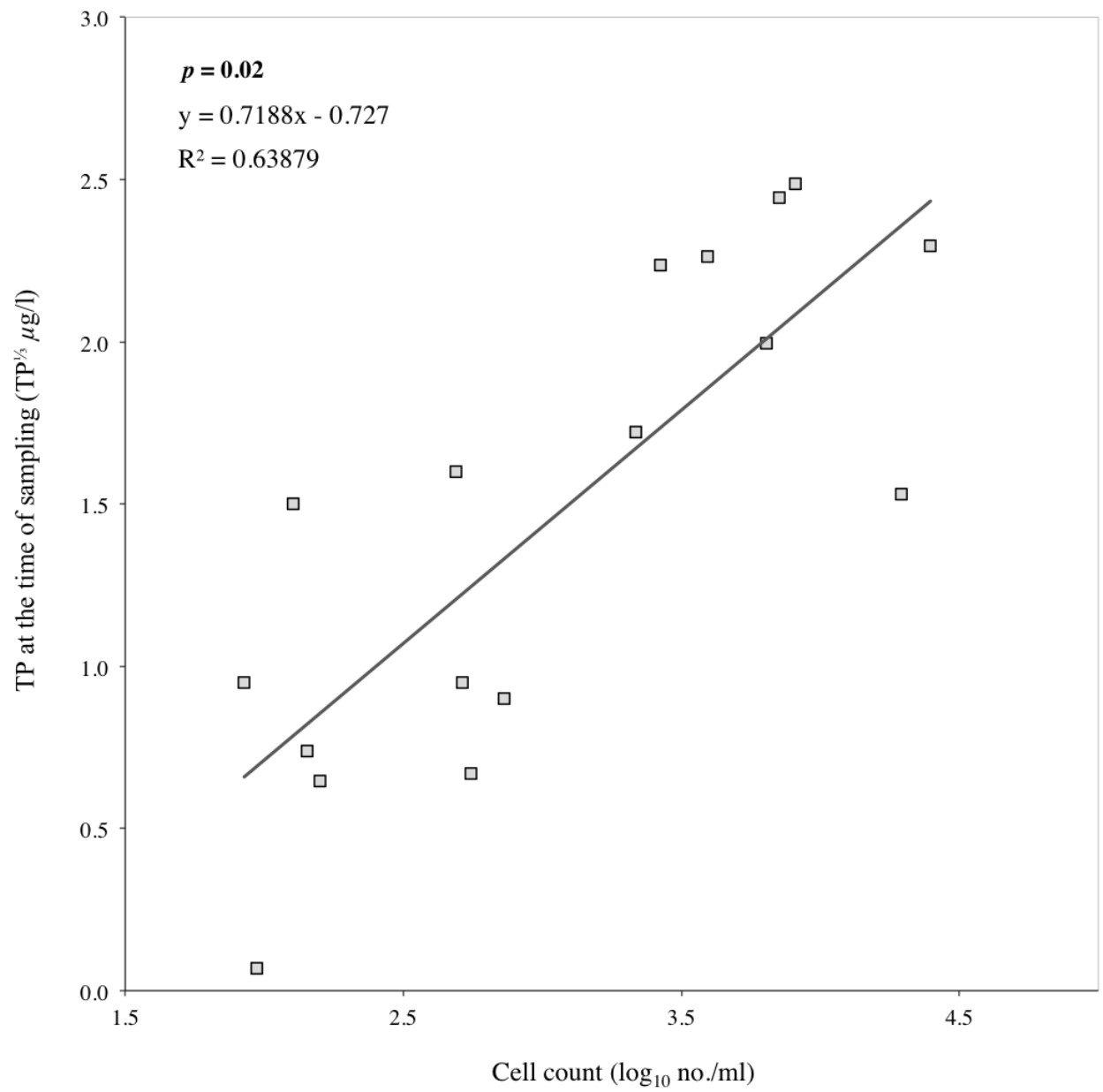

339 Figure 7. Correlation between cell count and TP concentrations from early June 2006 to late

340 September 2007 in all three lakes. The significance $(p)$ value was computed with SPSS on the

341 significance of the regression line.

342

The regression models obtained for TP and cell count (Figure 7), and those generated for

344 cell count and the concentration of metals per gram of cells (Eq. 1-8) were used to calculate the

345 best-fit values that describe the effect of changes in cell density on metal uptake by the

346 phytoplankton under different trophic states.

347 This was completed by firstly using the regression equation for TP and cell count (Figure

348 7) to estimate the number of cells per ml under a range of TP concentrations. These data were 
349 then incorporated into the following regression equations obtained from the analysis of the

350 metals and P per unit mass of phytoplankton and the corresponding cell count.

351

352

353

354

355

356

358

359

360

361

362

363

364

365

366

367

368

369

370

371

372

$\begin{array}{lr}\mathrm{Pb}=\left(\left(-1.888 \times \log _{10}(\text { cell count })\right)+9.973\right)^{3} & \text { Eq. } 1 \\ \mathrm{Hg}=\left(\left(-0.268 \times \log _{10}(\text { cell count })\right)+1.354\right)^{3} & \text { Eq. } 2 \\ \mathrm{Cd}=\left(\left(-0.874 \times \log _{10}(\text { cell count })\right)+5.813\right)^{3} & \text { Eq. } 3 \\ \mathrm{Cr}=\left(\left(-1.006 \times \log _{10}(\text { cell count })\right)+4.864\right)^{3} & \text { Eq. } 4 \\ \mathrm{Co}=\left(\left(-0.538 \times \log _{10}(\text { cell count })\right)+13.412\right)^{3} & \text { Eq. } 5 \\ \mathrm{Mn}=\left(\left(-0.967 \times \log _{10}(\text { cell count })\right)+2.572\right)^{3} & \text { Eq. } 6 \\ \mathrm{P}=\left(\left(-1.114 \times \log _{10}(\text { cell count })\right)+16.551\right)^{3} & \text { Eq. } 7\end{array}$

This generated best-fit values for each metal per gram of cells. For example, the $\mathrm{Hg}$ per gram of phytoplankton in water with a TP concentration of $30 \mu \mathrm{g} / 1$ was calculated as follows:

\section{- Phytoplankton cells per ml:}

$=10^{\wedge}\left(\left(0.7188 \times 30^{1 / 3}\right)-0.727\right)$

$=31.9$ cells

- Hg per gram of phytoplankton:

$=((-0.268 \times \log (31.9))+1.354)^{3}$

$=0.86 \mu \mathrm{g} / \mathrm{g}$

Table 4 provides details on how the predicted $\mathrm{Hg}$ concentrations change per gram of cells with a range of $\mathrm{TP}$ concentrations.

Table 4. Best-fit values of the number of phytoplankton cells per $\mathrm{ml}$ under a range of trophic states and the concentration of $\mathrm{Hg}$ per unit mass of those cells. The cells per ml were predicted using the regression formula generated for TP and cell counts in this study (Figure 7). 
373 Concentrations of $\mathrm{Hg}$ per $\mu \mathrm{g}$ of cells were estimated using the predicted cells per $\mathrm{ml}$ and the

374 regression equation for $\mathrm{Hg}$ per unit mass of phytoplankton (Eq. 2).

375

\begin{tabular}{|c|c|c|}
\hline TP $(\boldsymbol{\mu g} / \mathbf{l})$ & Phytoplankton cells per $\mathbf{m l}$ & Hg per unit mass of cells $(\boldsymbol{\mu g} \mathbf{g} \mathbf{g})$ \\
\hline 10 & 6.61 & 1.46 \\
12 & 8.27 & 1.36 \\
14 & 10.09 & 1.28 \\
16 & 12.09 & 1.20 \\
18 & 14.29 & 1.14 \\
20 & 16.68 & 1.08 \\
22 & 19.28 & 1.03 \\
24 & 22.09 & 0.98 \\
26 & 25.13 & 0.94 \\
28 & 28.40 & 0.90 \\
30 & 31.91 & 0.86 \\
\hline
\end{tabular}

376

377

Figure 8 shows the best-fit lines for the relationship of cell counts and the concentration

of $\mathrm{Hg}, \mathrm{Cd}, \mathrm{Cr}, \mathrm{Cu}, \mathrm{Co}, \mathrm{Mn}, \mathrm{Ni}$ and $\mathrm{Pb}$ per gram of cells. These were calculated in the same way

as described in detail for $\mathrm{Hg}$, with an extension of that data to include the range of TP values

380

recorded in this study $(7-85 \mu \mathrm{g} / 1)$. As the best-fit curves are without noise, and because they

381

represent the correlations in the data obtained from this study, they can be used to examine the

rate of metal uptake by phytoplankton cells in this study. The data points, i.e. the true

383

measurements recorded, were used in an exponential regression to quantitatively describe the

rate of uptake by the phytoplankton.

the phytoplankton is subject to exponential decay. This is characterised by an initially rapid

concentration approaches zero, where the rate of the absolute decrease in the metals decelerates.

389 The exponential regression equations for the data points in Figure 8 shows the decay constant,

390 which defines the rate of metal decay in phytoplankton cells with an increasing number of cells.

391 The larger the rate constant, the more rapid the decay of the dependant variable (y, metals in 
392 phytoplankton). The rate of $\mathrm{Pb}, \mathrm{Cd}, \mathrm{Cr}, \mathrm{Hg}, \mathrm{Cu}, \mathrm{Co}, \mathrm{Ni}$ and $\mathrm{Mn}$ decay in phytoplankton cells

393 with an increasing number of cells is $0.0046,0.0046,0.0045,0.0045,0.0037,0.0069,0.004$ and

$3940.0031(\mathrm{~mL} /$ cell) respectively. 

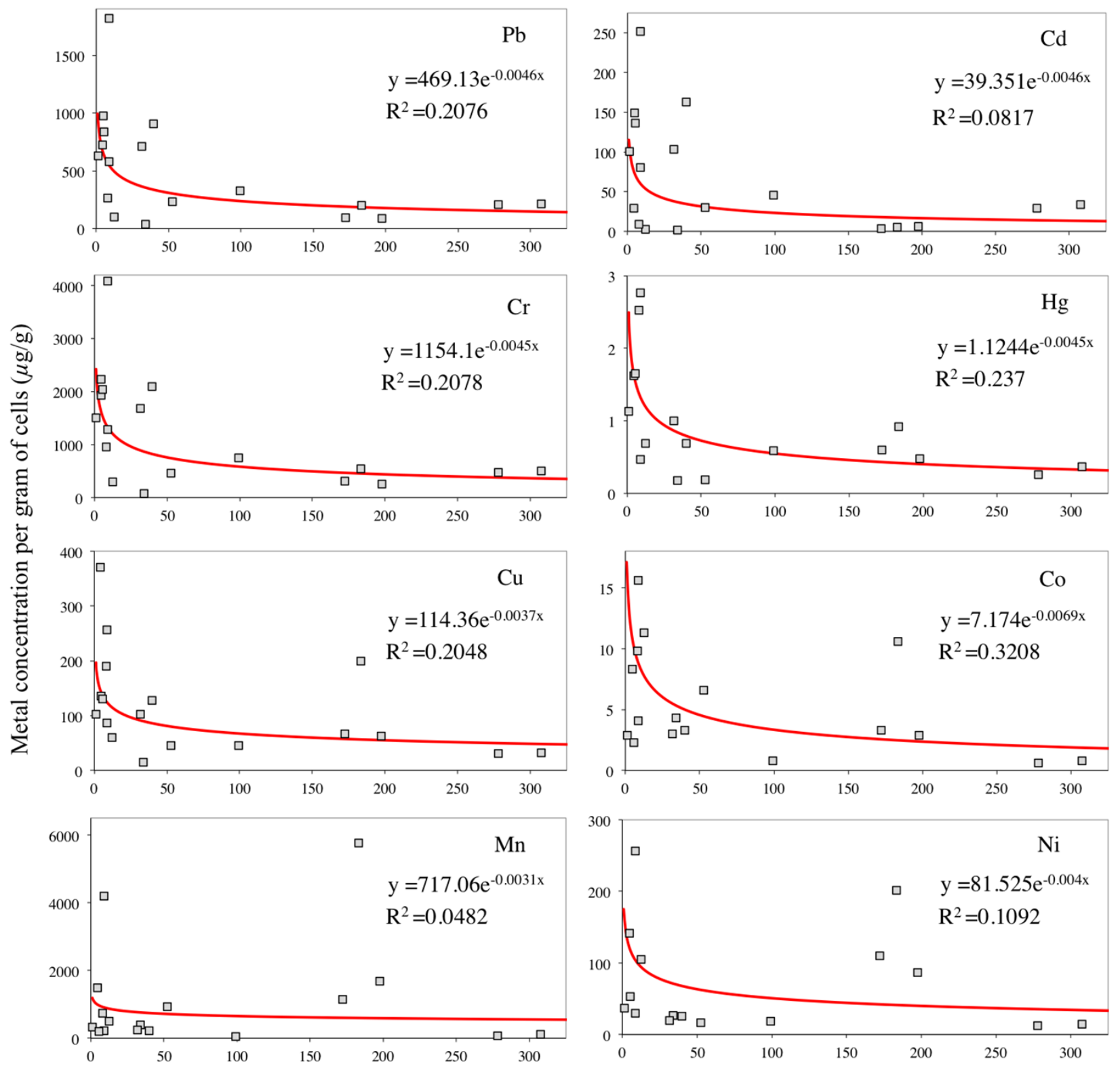

Cells per $\mathrm{ml}$ of lake water (cells $/ \mathrm{ml}^{-1}$ )

398 Figure 8. The relationship of phytoplankton cell counts with $\mathrm{Pb}, \mathrm{Cd}, \mathrm{Co}, \mathrm{Cu}, \mathrm{Cr}, \mathrm{Mn}, \mathrm{Ni}$ and $\mathrm{Hg}$

399 per gram of cells. The best-fit lines (in red) were calculated from the predicted cell counts

400 (Figure 7) and the metal (and P) concentrations per unit mass of cells (Figure 3). The data points

401 are the actual measurements recorded in this study and were used in the exponential regression

402 of the formula displayed for each relationship. 

cell count (Figure 7). The data points are the actual measurements recorded, and were used for the exponential regression analysis displayed to quantitatively describe the growth of cells in response to rising TP conditions. Figure 9 suggests that cell production with increased TP concentrations is subject to exponential growth. This is characterised by an initial gradual rise in cell count with increasing TP, but as more TP is introduced, the rate of growth accelerates.

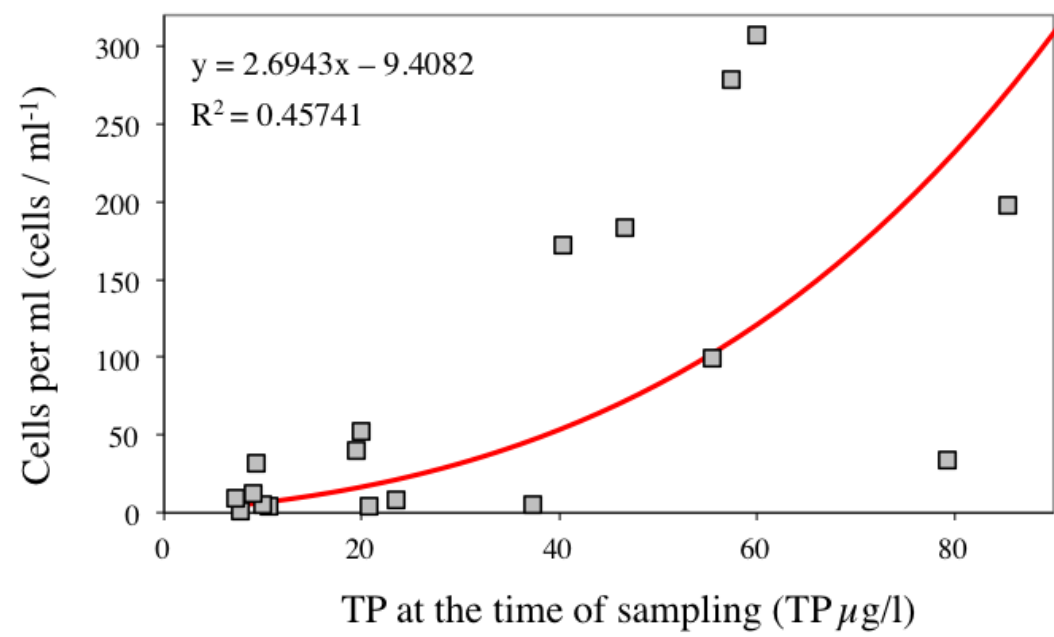

$\mathrm{TP}$ at the time of sampling (TP $\mu \mathrm{g} / \mathrm{l})$

412 Figure 9. The relationship of phytoplankton cell counts with TP concentrations. The best-fit line

413 was calculated from the regression analysis of TP and cell counts (Figure 7). The data points are

414 the actual measurements recorded in this study and were used in the exponential regression of

415 the formula displayed. 
419 phytoplankton cell count was 7.95 cells/ml and the mean phytoplankton biomass was $3.77 \mu \mathrm{g} / 1$

420 (Table 3). Therefore the weight of one cell is calculated as follows.

- Phytoplankton cell biomass $(\mu \mathrm{g} / \mathrm{l}) \div$ number of cells per litre (cells/l)

422 $=3.77 \mu \mathrm{g} / 1 \div 7950$ cells $/ 1$

423 $=4.74 \times 10^{-4} \mu \mathrm{g}$ (mean weight of one cell in Loch Doilet)

424 Secondly, the concentration of metals was calculated for one cell. This was carried out by using 425 the weight of one cell and the concentration of metal per unit weight of cells. The above cell 426 weight for Loch Doilet on the 22/03/2007 and the concentration of Cd per gram of cells will be 427 used as an example here.

- Weight of individual cell (g/cell) x Cd per gram of cells $(\mu \mathrm{g} / \mathrm{g})$ $=4.74 \times 10^{-10}(\mathrm{~g} /$ cell $) \times 8.5(\mu \mathrm{g} / \mathrm{g})$

430 $=4.03 \times 10^{-15} \mathrm{~g}$ of $\mathrm{Cd}$ per cell

431 Table 5 shows the calculated concentrations for $\mathrm{Hg}, \mathrm{Pb}, \mathrm{Cd}, \mathrm{Cu}, \mathrm{Cr}, \mathrm{Co}, \mathrm{P}, \mathrm{Mn}$ and $\mathrm{Ni}$ in the 432 phytoplankton cells of each of the lakes on all sampling occasions. 
Table 5. Content of $\mathrm{Pb}, \mathrm{Cd}, \mathrm{Hg}, \mathrm{Cr}, \mathrm{Co}, \mathrm{Ni}, \mathrm{Mn}, \mathrm{P}$ and $\mathrm{Cu}$ per phytoplankton cell in the three lakes on all sampling occasions. The

434

values were calculated from the average weight of one cell, and the metal (and P) concentrations per gram of cell on the same date.

435

\begin{tabular}{|c|c|c|c|c|c|c|c|c|c|c|}
\hline \multirow{2}{*}{ Lake } & \multirow{2}{*}{ Date } & \multicolumn{9}{|c|}{ Metal content per phytoplankton cell } \\
\hline & & $\begin{array}{c}\mathbf{P b} \\
\left(\mathrm{g} \times 1^{-15}\right)\end{array}$ & $\begin{array}{c}\mathrm{Cd} \\
\left(\mathrm{g} \times 10^{-15}\right) \\
\end{array}$ & $\begin{array}{c}\mathrm{Hg} \\
\left(\mathrm{g} \times 10^{-15}\right)\end{array}$ & $\begin{array}{c}\mathrm{Cr} \\
\left(\mathrm{g} \times 10^{-14}\right)\end{array}$ & $\begin{array}{c}\text { Co } \\
\left(\mathrm{g} \times 10^{-16}\right)\end{array}$ & $\begin{array}{c}\mathrm{Ni} \\
\left(\mathrm{g} \times 10^{-14}\right)\end{array}$ & $\begin{array}{c}\text { Mn } \\
\left(\mathrm{g} \times 10^{-14}\right)\end{array}$ & $\begin{array}{c}P \\
\left(\mathrm{~g} \times 10^{-12}\right)\end{array}$ & $\begin{array}{c}\mathrm{Cu} \\
\left(\mathrm{g} \times 10^{-14}\right)\end{array}$ \\
\hline Loch & 22.09 .06 & 906.6 & 139.0 & 1.5 & 207.5 & 77.3 & 13.2 & 138.2 & 1.8 & 12.6 \\
\hline Coire & 23.03 .07 & 1444.3 & 200.1 & 2.2 & 325.3 & 124.1 & 20.4 & 333.6 & 3.2 & 20.4 \\
\hline nan & 22.05 .07 & 14.5 & 0.4 & 0.1 & 3.0 & 16.4 & 1.0 & 14.8 & 0.2 & 0.6 \\
\hline \multirow{3}{*}{ Arr } & 21.06.07 & 343.7 & 44.4 & 0.3 & 68.2 & 97.5 & 2.5 & 137.9 & 6.0 & 6.7 \\
\hline & 25.07.07 & 90.2 & 12.5 & 0.1 & 20.0 & 6.4 & 0.5 & 3.3 & 0.7 & 1.3 \\
\hline & 01.09 .07 & 229.8 & 41.4 & 0.2 & 53.3 & 8.4 & 0.7 & 5.9 & 2.1 & 3.3 \\
\hline Loch & 22.09 .06 & 471.3 & 19.1 & 3.6 & 125.9 & 693.9 & 40.7 & 520.8 & 2.8 & 24.1 \\
\hline \multirow{5}{*}{ Doilet } & 23.03.07 & 4.3 & 0.1 & 0.0 & 1.2 & 4.7 & 0.4 & 2.1 & 0.1 & 0.3 \\
\hline & 22.05 .07 & 124.1 & 4.0 & 1.2 & 45.4 & 46.5 & 19.4 & 34.7 & 0.9 & 9.0 \\
\hline & 21.06 .07 & 9461.8 & 1509.8 & 16.9 & 2255.6 & 434.5 & 54.6 & 479.5 & 100.7 & 152.5 \\
\hline & 24.07 .07 & 273.6 & 44.6 & 0.5 & 66.6 & 7.5 & 1.7 & 6.6 & 2.1 & 4.3 \\
\hline & 31.08 .07 & 797.7 & 116.5 & 1.1 & 189.6 & 33.8 & 2.2 & 27.9 & 6.8 & 11.6 \\
\hline Loch & 21.09 .06 & 27.5 & 2.0 & 0.2 & 8.0 & 9.3 & 2.8 & 54.1 & 1.1 & 2.0 \\
\hline \multirow{5}{*}{ Urr } & 23.03 .07 & 92.4 & 3.2 & 0.6 & 29.9 & 32.5 & 10.8 & 113.1 & 1.7 & 6.5 \\
\hline & 23.05 .07 & 195.7 & 4.9 & 0.9 & 52.8 & 103.0 & 19.6 & 559.3 & 1.4 & 19.4 \\
\hline & 22.06 .07 & 230.4 & 31.9 & 0.4 & 52.1 & 5.6 & 1.3 & 4.1 & 3.7 & 3.1 \\
\hline & 26.07 .07 & 80.7 & 12.5 & 0.1 & 19.0 & 3.0 & 0.5 & 4.0 & 1.2 & 1.2 \\
\hline & 02.09 .07 & 333.6 & 46.9 & 0.4 & 76.7 & 9.6 & 2.0 & 11.9 & 4.0 & 4.9 \\
\hline
\end{tabular}




\section{Discussion}

439 As $\mathrm{P}$ is a limiting nutrient for phytoplankton growth, TP is a good measure of a lakes

440 trophic status (Brooks et al., 2001). From the range (maximum to minimum) of TP

441 concentrations recorded for each lake (Figure 2), the associated trophic status of the lakes ranges

442 from oligio- mesotropic for Loch Doilet (3.7-23.5 $\left.\mu \mathrm{g} \mathrm{TP} 1^{-1}\right)$, oligio- eutrophic for Loch Coire

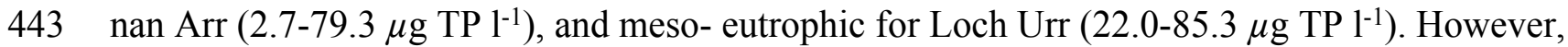

444 the trophic state of a lake is often judged in terms of mean TP concentrations (Carlson, 1977;

445 Knowlton and Jones, 1997; O'Gorman et al., 2004). If the mean TP concentrations over the

446 sampling period are used to assign a trophic status to the lakes in this study, that yields a status of

447 mesotrophic for Loch Coire nan Arr with a mean TP of $22.9 \mu \mathrm{g} / \mathrm{l}$, oligotrophic for Loch Doilet

$448\left(9.6 \mu \mathrm{g} \mathrm{TP}^{-1}\right)$, and eutrophic for Loch $\operatorname{Urr}\left(45.9 \mu \mathrm{g} \mathrm{TP}^{-1}\right)$. The variation in the mean trophic

449 state between the three lakes may be partially attributed to several differences in lake and

450 catchment morphometry. For example, Loch Doilet has the lowest mean TP concentration at 9.6

$451 \mu \mathrm{g} \mathrm{TP} 1^{-1}$ but has a lake volume $\left(4.2 \times 10^{6} \mathrm{~m}^{3}\right)$ that greatly exceeds that of the other two lakes

$452\left(5.0 \times 10^{5} \mathrm{~m}^{3}\right.$ in Loch Coire nan Arr, $2.4 \times 10^{6} \mathrm{~m}^{3}$ in Loch Urr). It also has a relatively higher

453 maximum lake depth recorded at approximately $16 \mathrm{~m}$ in comparison to a maximum depth of 12

$454 \mathrm{~m}$ recorded in the other two lakes (Table 1). A larger lake volume and maximum depth tends to

455 result in lower nutrient concentrations (Chow-Fraser, 1991). This is because firstly, a high

456 volume of lake water can dilute the TP, and secondly, at greater lake depths there is less

457 possibility of mixing and therefore $\mathrm{P}$ can be more readily removed from the water column by the

458 sediment to the lake bed (Jeppesen et al., 2003).

459 The correlation between TP and the number of cells per $\mathrm{ml}$ at the time of sampling was

460 significant at the $5 \%$ level (Figure 7), however the correlations between TP and cell surface area 
461 as well as biomass were not. Insignificance in the correlation of TP and surface area has been

462 previously noted by Thomann (1977) who suggests that the relationship is a combination of

463 biomass, TP, retention time, and sinking rates. It is possible that the measurements of

464 phytoplankton cell count, surface area and biomass in this study responded to TP at different

465 rates. For example, count can remain constant even if volume increases, but if the volume per

466 cell declines then the opposite applies, i.e. cell total volume remains constant but the number of

467 cells increases. Surface area can vary with either, for example a small spherical cell can have a

468 greater surface area to volume ratio than a larger spherical cell. Equally, the variations in the

469 correlations may also be because the method for the determination of cell count is open to less

470 error than that of cell surface area and/or biomass. The latter are an extension of the

471 determination of cell count and their final values include measurements of cell dimensions that

472 fit into an assigned geometric formula. Additionally, Gleskes and Kraay (1983) and Reynolds

473 (1984) shed doubt on the accuracy of the 'classical method' for the quantification of

474 phytoplankton growth. This is because it is based on spot samples that do not account for lateral

475 and vertical fluctuations in lake temperature, nutrients and light availability, as these strongly

476 influence the species composition and abundance of phytoplankton. Phycologists have also

477 recognised that phytoplankton biomass can never be accurately quantified due to diurnal

478 variations (Brian Whitton, personal communication, 2006). Furthermore, the abundance of

479 bacterioplankton and phytoplankton $<20 \mu \mathrm{m}$ are not accounted for in this investigation. As the

480 bacterioplankton and phytoplankton $<20 \mu \mathrm{m}$ can compete with algae for $\mathrm{P}$ in the water column

481 (Currie, 1990), a rise in TP concentrations in the samples analysed may not be accompanied by a

482 rise in phytoplankton growth indicators in another sample from that same environment.

483 Considering the significant relationship between TP and cell count, and that the use of cell count 
484 introduces the least error to the final result, it is perhaps more accurate to base interpretations of

485 phytoplankton growth and metal interactions on cell count as opposed to biomass or surface area.

486 The significant correlations between the mass-specific $\mathrm{Pb}, \mathrm{Cd}, \mathrm{Hg}, \mathrm{Cr}, \mathrm{Cu}$ and $\mathrm{Ni}$ in the

487 phytoplankton and TP concentrations (Figure 4) suggest that algae bloom density dilution

488 occurred in the lakes investigated. This evidence supports the findings of Pickhardt et al. (2002)

489 for algae bloom dilution of $\mathrm{Hg}$. It also relates to studies that have reported algae bloom dilution

490 of As (Chen and Folt, 2000), and polychlorinated biphenyls (Larsson et al., 1992).

491

Two mechanisms may explain these findings. Firstly is surface availability (Chen and

492 Folt, 2005). This means the phytoplankton share a finite pool of metals and have a constant

493 uptake. Thus enhanced lake productivity reduced the mass-specific metal concentrations. Yet it

494 is difficult to accept that surface availability controlled metal uptake by the phytoplankton alone

495 because the mass-specific concentrations of Mn showed no correlation with TP $\left(r^{2}=0.0004\right)$,

496 while Co (and P) showed no significant decline with increasing TP concentrations. Secondly,

497 because the trace element to macronutrient (i.e. phosphorus or carbon) ratios is a balance of net

498 steady-state uptake and growth rates (Sunda and Huntsman, 1997, 2004). As nutrients become

499 more available, growth rates increase, which eventually results in a decline in element to

500 phosphorus ratios in the cells. The significant correlations $(p<0.05)$ between the mass-specific

501 metal $(\mathrm{Pb}, \mathrm{Cd}, \mathrm{Cr}, \mathrm{Hg})$ to $\mathrm{P}$ ratios in phytoplankton and $\mathrm{TP}$ (Figure 5), and their negative

502 correlation against chlorophyll- $a$ appear to be in agreement with this biodilution hypothesis. This

503 also may explain why Mn showed no correlation with TP. Mn is an essential element for

504 phytoplankton growth (Morel et al., 1991), and so new cells may assimilate the available Mn.

505 Figure 9 indicates that the relationship of increasing TP and cell count is subject to

506 exponential growth (Serruya and Berman, 1975). Figure 8 suggests the relationship of increasing 
507 cell numbers and their $\mathrm{Hg}, \mathrm{Pb}, \mathrm{Cd}, \mathrm{Cu}, \mathrm{Co}, \mathrm{Ni}$ and $\mathrm{Cr}$ concentrations follows the pattern of

508 exponential decay. The association between Figure 8 and 9 provides potential insight into the

509 rate at which algae bloom dilution occurs. That is, as TP increases, phytoplankton cell growth

510 accelerates gently, and the concentration of metals in cells rapidly decline until it approaches

511 zero, where the rate of the absolute decrease in the metals reduces. This deceleration in algae

512 bloom dilution may eventually be paralleled by a lack of $\mathrm{P}$ to sustain the growth of more

513 phytoplankton or insufficient growth space.

514 The exponential relationships in Figure 8 also suggest that the selective uptake of metals

515 by the phytoplankton occurred (Santana-Casiano et al., 1995). If the decay constants in Figure 8

516 are examined, it is evident that the rate of $\mathrm{Pb}$ decay in phytoplankton with increasing cell number

517 is more rapid than $\mathrm{Cu}$ with respective decay constants of 0.0046 and 0.0037 . It is also evident

518 that algae bloom dilution is least effective on the most essential metal Mn with a decay constant

519 of 0.0031 . The differences in the rate constants of the algae bloom dilution suggest the

520 involvement of two intracellular mechanisms in the selective uptake of metals. One is metabolic,

521 which attempts to sustain the essential metals (e.g. Mn) concentrations (Sunda and Huntsman,

522 1998). The other is a detoxification process that stores excess $\mathrm{P}$ as intracellular polyphosphate,

523 which protects the cells by binding with metals in a detoxified form (Walsh and Hunter, 1995). If

524 the correlation between the ratios of metals to P in cells with TP in this study (Figure 5) is

525 consulted again, it is notable that the only metals that showed a significant decrease in their ratio

526 to $\mathrm{P}$ were $\mathrm{Pb}, \mathrm{Cd}, \mathrm{Hg}$ and $\mathrm{Cr}$. It is also notable that these four metals had a strikingly similar

527 decay constant with their relationship in phytoplankton to increasing cells. That is, 0.0046 for

528 both $\mathrm{Pb}$ and $\mathrm{Cd}$, and 0.0045 for $\mathrm{Cr}$ and $\mathrm{Hg}$ (Figure 8). Additionally, of the metals tested in this

529 study, these four metals are considered the most toxic to phytoplankton (Xue and Sigg, 1993). 
530 Therefore, it is possible that when nutrients became more available, growth rates and cellular $\mathrm{P}$

531 increased, forming intracellular polyphosphate bodies that selected less toxic metals more

532 rapidly.

533 Table 6 presents the metal to P stoichiometries (mol:mol) of the freshwater

534 phytoplankton collected in this study. The calculations were based on the mean concentrations of

535 the metals per cell in each of the three lakes (Table 5). These were converted to molar

536 concentrations and divided by the sum of all components, which included the $\mathrm{C}$ and $\mathrm{N}$ molar

537 concentrations based on the standard Redfield (1958) ratio of $\mathrm{C}_{106}: \mathrm{P}_{1}: \mathrm{N}_{16}$. Table 6 shows the

538 ratios of the metals between the lakes are in the same order of magnitude. The mean metal to $\mathrm{P}$

539 stoichiometry from this investigation is

$540\left(\mathrm{C}_{106} \mathrm{P}_{1} \mathrm{~N}_{16}\right)_{1000} \mathrm{~Pb}_{0.019} \mathrm{Hg}_{0.00004} \mathrm{Cu}_{0.013} \mathrm{Cd}_{0.005} \mathrm{Cr}_{0.2} \mathrm{Co}_{0.0008} \mathrm{Mn}_{0.2} \mathrm{Ni}_{0.012}$. This is similar to the

541 phytoplankton cell stoichiometry presented by Twining et al. (2004) who found, for instance,

$5420.26 \mathrm{~mol}$ of Mn for every $1 \mathrm{~mol}$ of P, whereas this study found $0.21 \mathrm{~mol}$ of Mn for every $1 \mathrm{~mol}$

543 of P. The slightly higher ratio offered by Twining et al. may be expected as their study was on

544 marine phytoplankton. This is because $\mathrm{P}$ is generally more concentrated in the phytoplankton of

545 freshwater lakes, and thus lowering the metal to P ratio.

546

547 Table 6. Metal to P stoichiometries (mol:mol) of the freshwater phytoplankton collected in Loch

548 Coire nan Arr, Loch Doilet and Loch Urr for this study. Calculations were based on the mean

549 concentrations of the metals per cell in the three lakes (Table 5). These were then converted to

550 molar concentrations, and divided by the sum of all components, which included $\mathrm{C}$ and $\mathrm{N}$ molar

551 concentrations that were calculated based on the standard Redfield (1958) ratio of $\mathrm{C}_{106}: \mathrm{P}_{1}: \mathrm{N}_{16}$. 
552 The averages of the ratios across the lakes yields a mean metal to P stoichiometry of

$553\left(\mathrm{C}_{106} \mathrm{P}_{1} \mathrm{~N}_{16}\right)_{1000} \mathrm{~Pb}_{0.019} \mathrm{Hg}_{0.00004} \mathrm{Cu}_{0.013} \mathrm{Cd}_{0.005} \mathrm{Cr}_{0.2} \mathrm{Co}_{0.0008} \mathrm{Mn}_{0.2} \mathrm{Ni}_{0.012}$.

554

555

\begin{tabular}{|c|rrr|r|}
\hline Element & $\begin{array}{c}\text { Loch Coire } \\
\text { nan Arr }\end{array}$ & Loch Doilet & Loch Urr & \multicolumn{1}{c|}{ Mean } \\
\hline $\mathbf{C}$ & 105860 & 106197 & 105989 & 106015 \\
$\mathbf{N}$ & 15979 & 16030 & 15998 & 16002 \\
$\mathbf{P}$ & 999 & 1002 & 1000 & 1000 \\
$\mathbf{P b}$ & 0.03 & 0.01 & 0.01 & 0.019 \\
$\mathbf{H g}$ & 0.00005 & 0.00003 & 0.00003 & 0.00004 \\
$\mathbf{C u}$ & 0.02 & 0.01 & 0.01 & 0.013 \\
$\mathbf{C d}$ & 0.009 & 0.004 & 0.002 & 0.005 \\
$\mathbf{C r}$ & 0.3 & 0.1 & 0.1 & 0.2 \\
$\mathbf{C o}$ & 0.001 & 0.001 & 0.001 & 0.0008 \\
$\mathbf{M n}$ & 0.3 & 0.1 & 0.3 & 0.2 \\
$\mathbf{N i}$ & 0.01 & 0.01 & 0.01 & 0.012 \\
\hline
\end{tabular}

556

The calculated stoichiometry may be used to estimate the concentration of metals per

557 phytoplankton cell in the lakes based on cell size. If the average biomass of one cell is $1.55 \times 10^{-}$

$558{ }^{10} \mathrm{~g}$, and using the $\mathrm{Cd}$ : P ratio of $0.000005 / 1$, the estimated $\mathrm{Cd}$ concentration bound to a cell is

$5597.76 \times 10^{-16} \mathrm{~mol}$ (or $87.2 \times 10^{-15} \mathrm{~g}$ ). If the $\mathrm{P}$ concentration is raised by a factor of 4 , the estimated

$560 \mathrm{Cd}$ is $3.11 \times 10^{-18} \mathrm{~mol}$ (or $3.49 \times 10^{-16} \mathrm{~g}$ ). The risk of toxicity can then be predicted by

561 comparing the results to those of toxicity tests. For instance, Wang and Dei (2006) observed

562 toxicity at a $\mathrm{Cd}: \mathrm{P}$ ratio of $>0.2$. While this may be useful, using the stoichiometry as a predictor

563 on a wider scale than the lakes investigated has large uncertainties because it would assume the

564 ratio is constant.

565

566

\section{Conclusions}

567

1. A higher TP concentration in the lakes resulted in significant algae growth dilution of

568 the mass-specific $\mathrm{Pb}, \mathrm{Cd}, \mathrm{Hg}, \mathrm{Cu}, \mathrm{Ni}$ and $\mathrm{Cr}$ in the phytoplankton. This was because the

569 available metals had to be shared among more and as $\mathrm{P}$ became more available, the mass specific 
570 metal to P ratios in the phytoplankton declined. The same mechanisms were not effective on $\mathrm{Mn}$

571 because it is assimilated during phytoplankton growth.

572 2. The relationship between the number of phytoplankton cells per millilitre of lake water 573 and the mass-specific metal concentrations in the phytoplankton provides an examination of the 574 rate of algae bloom dilution in the lakes. As TP increased, phytoplankton cell growth accelerated 575 gradually, and the concentration of metals in cells rapidly declined until it approached zero. The 576 decay constants indicate that $\mathrm{Mn}$ has the lengthiest rate of algae bloom dilution among the

577 metals. This suggests the involvement of two intracellular mechanisms in the active selection of 578 metals. The first is metabolic in that growing cells have preference for Mn and thus it is diluted 579 at a more gradual rate. The second is a detoxification process that stores excess $\mathrm{P}$ as intracellular 580 polyphosphate, which selects the less toxic metals more rapidly.

3. The simultaneous measurements of metals and $\mathrm{P}$ in phytoplankton cells, along with

582 quantification of changes in cell mass, generated a mean metal to P stoichiometry of

$583\left(\mathrm{C}_{106} \mathrm{P}_{1} \mathrm{~N}_{16}\right)_{1000} \mathrm{~Pb}_{0.019} \mathrm{Hg}_{0.00004} \mathrm{Cu}_{0.013} \mathrm{Cd}_{0.005} \mathrm{Cr}_{0.2} \mathrm{Co}_{0.0008} \mathrm{Mn}_{0.2} \mathrm{Ni}_{0.012}$ based on the Redfield

584 average $\mathrm{C}, \mathrm{N}$ and $\mathrm{P}$ stoichiometry of $\left(\mathrm{CH}_{2} \mathrm{O}\right)_{106}\left(\mathrm{NH}_{3}\right)_{16} \mathrm{H}_{3} \mathrm{PO}_{4}$. This stoichiometry can be used to

585 estimate the concentration of metals in cells based on their P content and may be incorporated

586 into BLM if the concentration of cell surfaces were to be used as the biotic ligands. 
589

590

591

592

593

594

595

596

597

598

599

600

601

602

603

604

605

606

607

608

609

610

611

612

613

614

615

616

617

618

619

620

621

622

623

624

625

626

627

628

629

630

631

632

633

\section{References}

Bock R. 1979. A handbook of decomposition methods in analytical chemistry. International Textbook Company.

Bruland KW, Knauer GA and Martin JH. 1978. Cd in northeast Pacific waters. Limnology and Oceanography, 23: 618-625.

Chen CY and Folt CL. 2000. Bioaccumulation and diminution of arsenic and lead in a freshwater food web. Environmental Science and Technology, 34: 3878-3884.

Chen CY and Folt CL. 2005. High plankton densities reduce mercury biomagnification. Environmental Science and Technology, 39: 115-121.

Currie, D. J. (1990). Large-scale variability and interactions among phytoplankton, bacterioplankton, and phosphorus. Limnology and Oceanography, 35: 1437-1455.

De Schamphelaere KAC, Stauber JL, Wilde KL, Markich SJ, Brown PL, Franklin NM, Creighton NM and Janssen CR. 2005. Toward a Biotic Ligand Model for freshwater green algae: surface-bound and internal copper are better predictors of toxicity than free $\mathrm{Cu}^{2+}$-ion activity when pH is varied. Environmental Science and Technology, 39: 2067-2072.

Di Toro DM, Allen HE, Bergman HL, Meyer JS, Paquin PR and Santore RC. 2002. Biotic ligand model of the acute toxicity of metals. 1. Technical basis. Environmental Toxicology and Chemistry, 20: 2383-2396.

Donald NM. 2004. Interactions of trace metals with phytoplankton and zooplankton in Lough Neagh, Northern Ireland. Ph.D. thesis, University of Ulster, Coleraine, Northern Ireland.

Douglas RW, Rippey B. 2000. The random redistribution of sediment by wind in a lake. Limnology and Oceanography, 45(3): 686-694. doi: 10.4319/lo.2000.45.3.0686.

Douglas RW, Rippey B, Gibson CE. 2003. Estimation of the in-situ settling velocity of particles in lakes using a time series sediment trap. Freshwater Biology, 48: 512-518. doi: 10.1046/j.1365-2427.2003.01027.

Eisenreich SJ, Bannerman RT and Armstrong DE. 1975. A simplified phosphorus analysis technique. Environmental Letters, 9: 43-53.

Flower RJ, Rippey B, Rose NL, Appleby PG and Batterbee RW. 1994. Palaeolimnology evidence for the acidification and contamination of lakes by atmospheric pollution in western Ireland. Journal of Ecology, 82: 581-596.

Gormley AM. 2008. The impact of phytoplankton growth on the biogeochemical cycling of metals in lakes. British Library, Access through EThOS:

http://ethos.bl.uk/OrderDetails.do?uin=uk.bl.ethos.529532. 
634

635 Gormley-Gallagher AM, Douglas RW and Rippey B. 2015. The Applicability of the Distribution 636 Coefficient, $\mathrm{K}_{\mathrm{D}}$, Based on Non-Aggregated Particulate Samples from Lakes with Low

637

638

639

640

641

642

643

644

645

646

647

648

649

650

651

652

653

654

655

656

657

658

659

660

661

662

663

664

665

666

667

668

669

670

671

672

673

674

675

676

677

678

Suspended Solids Concentrations. PLoS ONE, 10(7): e0133069. doi:

10.1371/journal.pone.0133069.

Guan R and Wang WX. 2004. Cd and Zn uptake kinetics in Daphnia magna in relation to Cd exposure history. Environmental Science and Technology, 38: 6051-6058.

Hillebrand H, Durselen CD, Kirschtel D, Pollingher U and Zohary T. 1999. Biovolume calculation for pelagic and benthic microalgae. Journal of Phycology, 39: 1145-1159.

Hilton J. 1985. A conceptual framework for predicting the occurrence of sediment focusing and sediment redistribution in small lakes. Limnology and Oceanography, 30: 1131-1143. doi: 10.4319/1o.1985.30.6.1131.

Ho TY, Quigg A, Finkel ZV, Milligan AJ, Wyman K, Falkowski PG and Morel FMM. 2003. The elemental composition of some marine phytoplankton. Journal of Phycology, 39: 11451159.

Ho TY, Wen LS, You CF and Lee DC. 2007. The trace-metal composition of size-fractioned plankton in the South China Sea: biotic versus abiotic sources. Limnology and Oceanography, 52(5): 1776-1788. doi: 10.4319/1o.2007.52.5.1776.

Hudson RJM and Morel FMM. 1990. Iron transport in marine phytoplankton: Kinetics of cellular and medium coordination reactions. Limnology and Oceanography, 35: 1002-1020.

John DM, Whitton BA and Brook AJ. 2002. The Freshwater Algal Flora of the British Isles: An Identification Guide to Freshwater and Terrestrial Algae. The National History Museum, London.

Kelly M. 2000. Identification of common benthic diatoms in rivers. Field Studies, 9: 583-700.

Larsson P, Collivin L, Okia L and Meyer G. 1992. Lake productivity and water chemistry as governs of the uptake of persistent pollutants in fish. Environmental Science and Technology, 26: $346-352$.

Lohan MC, Crawford DW, Purdie DA and Statham PJ. 2005. Iron and zinc enrichments in the northeast subarctic Pacific: Ligand production and zinc availability in response to phytoplankton growth. Limnology and Oceanography, 50: 1427-1437.

Long SE, Martin TD and Martin ER. 1990. Method 200.8- Determination of trace elements in waters and wastes by Inductively Coupled Plasma-Mass Spectrometry. Office of Research and Development, United States Environmental Protection Agency (USEPA). 
679 Luengen AC, Raimondi PT and Flegal AR. 2007. Contrasting biogeochemistry of six trace

680 metals during the rise and decay of a spring phytoplankton bloom in San Francisco Bay.

681 Limnology and Oceanography, 52: 1112-1130.

682

683

Ma Z, Jacobsen FE and Giedroc DP. 2009. Metal transporters and metal sensors: how

684 coordination chemistry controls bacterial metal homeostasis. Chemistry Reviews, 109: 4644-

6854681.

686

687

Menden-Deuer SE, Lessard S and Satterberg S. 2001. Effect of preservation on dinoflagellate

688

689

690

691

692

693

694

695

696

697

698

699

700

701

702

703

704

705

706

707

708

709

710

711

712

713

714

715

716

and diatom cell volume and consequences for carbon biomass predictions. Marine Ecology Progress Series, 222: 41-50.

Moffett JW, Brand LE, Croot PL and Barbeau KA. 1997. Cu speciation and cyanobacterial distribution in harbors subject to anthropogenic $\mathrm{Cu}$ inputs. Limnology and Oceanography, 42: 789-799.

Monteith DT and Shilland EM. 2007. The United Kingdom Acid Waters Monitoring Network assessment of the first 18 years of data. Report to the Department for Environment, Food and Rural Affairs (Contract EPG 1/3/160). Available at: http://awmn.defra.gov.uk/resources/interpreports/18yearInterpRpt.pdf

Morel FMM, Hudson RJM and Price NM. 1991. Limitation of productivity by trace metals in the sea. Limnology and Oceanography, 36: 1742-1755.

Murphy J and Riley JP. 1962. A modified single-solution method for the determination of phosphate in natural waters. Analytical Chimcia Acta, 27: 31-36.

Murphy JF, Winterbottom JH, Orton S, Simpson GL, Shilland EM and Hildrew AG. 2014. Evidence of recovery from acidification in the macroinvertebrate assemblages of UK fresh waters: a 20-year time series. Ecological Indicators, 37: 330-340.”

Murray JW. 1987. Mechanisms controlling the distribution of trace elements in oceans and lakes. In: R. A. Hites and S. Eisenreich (eds.). Sources and Fates of Aquatic Pollutants. American Chemical Society, Washington DC. 153-184pp.

Olrik K, Blomqvist P, Brettum P, Cronberg G and Eloranta P. 1998. Methods for Quantitative Assessment of Phytoplankton in Freshwaters part I. Stockholm: Naturvårdsverket för lag: 86.

Paquin PR, Zoltay V, Winfield RP Wu KB, Mathew R, Santore RC and Di Toro DM. 2002. Extension of the biotic ligand model of acute toxicity to a physiologically-based model of the survival time of rainbow trout (Oncorhynchus mykiss) exposed to silver. Comparative

720

721

722

723

724 Biochemistry and Physiology Part C: Toxicology and Pharmacology, 133: 305-343.

Patrick S, Monteith DT and Jenkins A. 1995. UK Acid Waters Monitoring Network: The First Five Years- Analysis and Interpretation of Results, April 1988 - March 1993. London, ENSIS Publishing. 
725

726

727

728

729

730

731

732

733

734

735

736

737

738

739

740

741

742

743

744

745

746

747

748

749

750

751

752

753

754

755

756

757

758

759

760

761

762

763

764

765

766

767

768

769

770
Pickhardt PC, Folt CL, Chen CY, Klaue B, Blum JD. 2002. Algal blooms reduce the uptake of toxic methylmercury in freshwater food webs. Proceedings of the National Academy of Sciences, 99: 4419-4423.

Redfield AC. 1958. The biological control of chemical factors in the environment. American Scientist, 46: 205-221.

Redfield AC, Ketchum BH and Richards FA. 1963. The influence of organisms and the composition of seawater. In: The Sea. M. N. Hill (Ed.), Wiley Interscience, New York: 26-77pp.

Reynolds GL and Hamilton-Taylor J. 1992. The role of planktonic algae in the cycling of Zn and $\mathrm{Cu}$ in a productive soft-water lake. Limnology and Oceanography, 37: 1759-1769.

Riemann B. 1978. Absorption coefficients for chlorophyll a and b in methanol and comment on the interference of chlorophyll $b$ in determination of chlorophyll $a$. Vatten, 3: 187-194.

Rippey B and Douglas RW. 2004.. Reconstructing regional-scale lead contamination of the atmosphere (1850-1980) in the United Kingdom and Ireland using lake sediments. Global Biogeochemical Cycles, 18: GB4.26, doi:10.1029/2004GB002305.

Santana-Casiano JM, Gonzalez-Davila M, Perez-Pena J and Millero FJ. 1995. $\mathrm{Pb}^{2+}$ interactions with the marine phytoplankton Dunaliella tertiolecta. Marine Chemistry, 48: 115-129.

Sanudo-Wilhelmy SA, Tovar-Sanchez A, Fu FX, Capone DG, Carpenter EJ and Hutchins DA. 2004. The impact of surface-adsorbed phosphorus on phytoplankton Redfield stoichiometry.

Nature, 432: 897-901.

Serruya C and Berman T. 1975. Phosphorus, nitrogen and the growth of algae in Lake Kinneret. Journal of Phycology, 11: 155-162.

Sigg L. 1985. Metal transfer mechanisms in lakes; the role of settling particles. In W. Stumm [ed.], Chemical processes in lakes. Wiley- Interscience, New York, p. 283-310.

Sigg L, Sturm M and Kistler D. 1987. Vertical transport of heavy metals by settling particles in Lake Zurich. Limnology and Oceanography, 32: 112-130.

Smith VH. 1985. Predictive models for the biomass of blue-green algae in lakes. Water Resources Bulletin, 21(3): 433-439.

Sunda WG and Huntsman SA. 1997. Interrelated influence of iron, light and cell size on marine phytoplankton growth. Nature, 390: 389-392.

Sunda WG and Huntsman SA. 1998. Processes regulating cellular metal accumulation and physiological effects: Phytoplankton as model systems. The Science of the Total Environment, 219: $165-181$. 
771

772

773

774

775

776

777

778

779

780

781

782

783

784

785

786

787

788

789

790

791

792

793

794

795

796

797

798

799

800

801

802

803

804

805

806

807

808

809

810

811

812

813

814

815

816

Sunda WG and Huntsman SA. 2004. Relationships among photoperiod, carbon fixation, growth, chlorophyll a, and cellular iron and zinc in a coastal diatom. Limnology and Oceanography, 49: 1742-1753.

Sykes JM, Lane AMJ and George GD. 1999. The United Kingdom Environmental Change Network: Protocols for Standard Measurements at Freshwater Sites. Centre for Ecology and Hydrology, U.K., National Environmental Research Council.

Twining BS, Baines SB and Fisher NS. 2004. Element stoichiometries of individual plankton cells collected during the Southern Ocean Iron Experiment (SOFeX). Limnology and Oceanography, 49: 2115-2128.

U.S. EPA. 2006. Standard Operating Procedures (8) - Sampling Equipment Decontamination. U.S. Environmental Protection Agency (EPA) Environmental Response Team, Response Engineering and Analytical Contract, SOP, Rev. 3.0, 1/23/92.

Vasconcelos MTSD, Leal MFC, van den Berg CMG. 2002. Influence of the nature of the exudates released by different marine algae on the growth, trace metal uptake and exudation of Emiliania huxleyi in natural seawater. Marine Chemistry, 77: 187-210.

Vollenweider RA. 1974. A Manual on Methods for Measuring Primary Production in Aquatic Environments. I.B.P. Handbook No. 12. Blackwell Scientific Publications, Oxford.

Walsh RS and Hunter KA. 1995. Influence of phosphorus storage on the uptake of cadmium by the marine alga Macrocystis pyrifera. Limnology and Oceanography, 37: 1361-1369.

Wang WX and Dei RCH. 2006. Metal stoichiometry in predicting Cd and Cu toxicity to a freshwater green alga Chlamydomonas reinhardtii. Environmental Pollution, 142: 303-312.

Whitfield M. 2001. Interactions between phytoplankton and trace metals in the ocean. Advances in Marine Biology, 41: 3-128.

Whitton BA, Balbi DM and Donaldson A. 2003. Blue-green Algae of the British Isles Interactive Key to the Species. (CD-ROM) School of Biological and Biomedical Sciences, University of Durham, ISBN 0-9538842-0-1.

Whitton BA, Balbi DM, John DM, Eilwood NTW, York PV and Donaldson A. 2002. Green Algae of the British Isles. Interactive Key to the Commoner Genera and Species. (CD-ROM produced in collaboration with The Natural History Museum, London and the Environment Agency of England and Wales) School of Biological and Biomedical Sciences, University of Durham, Durham ISBN -0-9538842-3-6.

Xue H and Sigg L. 1993. Free cupric ion concentration and $\mathrm{Cu}(\mathrm{II})$ speciation in a eutrophic lake. Limnology and Oceanography, 38(6): 1200-1213. 
817 Yu M, Sun D, Huang R, Tian W, Shen W, Zhang H and Xu N. 2003. Determination of ultra-

818 trace gold in natural water by graphite furnace atomic absorption spectrophotometry after in situ

819 enrichment with thiol cotton fiber. Analytica Chimica Acta, 479: 225-231. 
